\title{
Seasonal dynamics of organic carbon and metals in thermokarst lakes from the discontinuous permafrost zone of western Siberia
}

\author{
R. M. Manasypov ${ }^{1}$, S. N. Vorobyev $^{1}$, S. V. Loiko ${ }^{1}$, I. V. Kritzkov ${ }^{1}$, L. S. Shirokova ${ }^{2,3}$, V. P. Shevchenko ${ }^{4}$, \\ S. N. Kirpotin ${ }^{1}$, S. P. Kulizhsky ${ }^{1}$, L. G. Kolesnichenko ${ }^{1}$, V. A. Zemtzov ${ }^{1}$, V. V. Sinkinov ${ }^{1}$, and O. S. Pokrovsky ${ }^{1,2}$ \\ ${ }^{1}$ Tomsk State University, 634050, Tomsk, 36 Lenin av., Tomsk, Russia \\ ${ }^{2}$ Geosciences and Environnement Toulouse, UMR 5563 CNRS, Université de Toulouse, \\ 14 avenue Edouard Belin, 31400, Toulouse, France \\ ${ }^{3}$ Institute of Ecological Problems of the North UroRAS, 163061, Arkhangelsk, Nab. Severnoj Dviny, 23, Arkhangelsk, Russia \\ ${ }^{4}$ P. P. Shirshov Institute of Oceanology of the Russian Academy of Sciences, 36 Nakhimovsky Prospekt, \\ 117997 Moscow, Moscow, Russia
}

Correspondence to: O. S. Pokrovsky (oleg@get.obs-mip.fr)

Received: 3 December 2014 - Published in Biogeosciences Discuss.: 30 January 2015

Revised: 20 April 2015 - Accepted: 30 April 2015 - Published: 21 May 2015

\begin{abstract}
Despite relatively good knowledge of the biogeochemistry of Siberian thermokarst lakes during summer base flow, their seasonal dynamics remains almost unexplored. This work describes the chemical composition of $\sim 130$ thermokarst lakes ranging in size from a few $\mathrm{m}^{2}$ to several $\mathrm{km}^{2}$, located in the discontinuous permafrost zone. Lakes were sampled during spring flood, just after the ice break (early June), the end of summer (August), the beginning of ice formation (October) and during the full freezing season in winter (February). The lakes larger than $1000 \mathrm{~m}^{2}$ did not exhibit any statistically significant control of the lake size on dissolved organic carbon (DOC), the major and trace element concentrations over three major open water seasons. On the annual scale, the majority of dissolved elements including organic carbon increased their concentration from 30 to $500 \%$, with a statistically significant $(p<0.05)$ trend from spring to winter. The concentrations of most trace elements (TEs) increased in the order spring $>$ summer $>$ autumn $>$ winter. The ice formation in October included several stages: first, surface layer freezing followed by crack (fissure) formation with unfrozen water from the deeper layers spreading over the ice surface. This water was subsequently frozen and formed layered ice rich in organic matter. As a result, the DOC and metal (Mn, Fe, Ni, Cu, Zn, As, Ba and Pb) concentrations were highest near the surface of the ice column $(0$ to $20 \mathrm{~cm})$ and decreased by a factor of 2 towards the bottom. The main implications of discovered freeze-driven so-
\end{abstract}

lute concentrations in thermokarst lake waters are enhanced colloidal coagulation and removal of dissolved organic matter and associated insoluble metals from the water column to the sediments. The measured distribution coefficients of a TE between amorphous organo-ferric coagulates and lake water $(<0.45 \mu \mathrm{m})$ were similar to those reported earlier for Fe-rich colloids and low molecular weight $(<1 \mathrm{kDa}$, or $<1-2 \mathrm{~nm})$ fractions of thermokarst lake waters, suggesting massive coprecipitation of TE with amorphous Fe oxyhydroxide stabilized by organic matter. Although the concentration of most elements was lowest in spring, this period of maximal water coverage of land created a significant reservoir of DOC and soluble metals in the water column that can be easily mobilized to the hydrological network. The highest DOC concentration observed in the smallest $\left(<100 \mathrm{~m}^{2}\right)$ water bodies in spring suggests their strongly heterotrophic status and, therefore, a potentially elevated $\mathrm{CO}_{2}$ flux from the lake surface to the atmosphere.

\section{Introduction}

Western and central Siberia's thermokarst (thaw) lakes extend over a territory spanning over 1 million $\mathrm{km}^{2}$ (half of the western Siberia lowland, 0.5 million $\mathrm{km}^{2}$, and all of the northern Siberia lowland, 0.84 million $\mathrm{km}^{2}$ ). They are highly dynamic hydrochemical systems that receive chemical ele- 
ments from the atmosphere and surrounding peat soil and exchange greenhouse gases (GHGs) with the atmosphere, delivering dissolved carbon and metals to adjacent hydrological systems. Because more permafrost will continue to thaw due to climate warming, which is heavily intensified in this region (Frey and Smith, 2005), the directions and magnitude of lakes-rivers exchange processes may be significantly modified, seriously affecting the biogeochemical fluxes both on land and in the coastal zone of the Arctic Ocean.

In contrast to the relatively good understanding of western Siberia thermokarst lakes functioning during the active (summer) season (Walter et al., 2006, 2008; Walter Anthony et al., 2012; Audry et al., 2011; Pokrovsky et al., 2011, 2013, 2014; Shirokova et al., 2009, 2013; Karlsson et al., 2012, 2014; Manasypov et al., 2014), the intra-annual variations of lake water chemistry including the glacial period and spring flood have remained, up to the present time, virtually unexplored. At the same time, the glacial season is extremely important in GHG regulation in boreal and subarctic lakes, due to significant accumulation of gases under the ice and their liberation during the ice melting (Karlsson et al., 2013). Similarly, the ice formation period provides important insights into the solute concentration and colloid coagulation mechanisms, given the main particularity of shallow $(0.3$ to $1.0 \mathrm{~m}$ deep) thermokarst lakes in western Siberia - their full freezing during winter (Pokrovsky et al., 2011, 2014). The possibility of complete freezing of western Siberia thermokarst lakes contrasts with the majority of other circumpolar water bodies, such as from the Kolyma lowland (Walter Anthony et al., 2014), the Lena Delta (Boike et al., 2013) and the Mackenzie Delta plain (Tank et al., 2009, 2011; Grosse et al., 2013; Walter Anthony and Anthony, 2013), which often have a depth of more than $2 \mathrm{~m}$ and as such do not freeze to the bottom, while exhibiting chemical and thermal stratification of the water column. Another important difference of thermokarst western Siberia lakes from well-studied river delta/river valley lakes is the lack of a connection to the underground network in the former. Therefore, lake connection to the hydrological network may occur only via surface flow (Kirpotin et al., 2008), without subsurface flow. Among all studied circumpolar water bodies, shallow ponds of the north of Canada (Laurion et al., 2010; Negandhi et al., 2013; Bouchard et al., 2014) seem to be most similar to western Siberian thermokarst lakes. However, in a recent compilation of studied circumpolar ponds (Rautio et al., 2011), only 1 region among 16 (thaw ponds of Boniface, Quebec) exhibits a $\mathrm{pH}$ of $5.4 \pm 0.6$, a Cond. (specific conductivity) of $18 \mu \mathrm{S} \mathrm{cm}^{-1}$ and DOC of $13.4 \pm 4.7$, which is comparable to highly diluted $\left(5<\right.$ Cond $\left.<20 \mu \mathrm{S} \mathrm{cm}^{-1}\right)$, acidic $(3.5 \leq \mathrm{pH} \leq 5.5)$, and humic $\left(10 \leq \mathrm{DOC} \leq 40 \mathrm{mg} \mathrm{L}^{-1}\right)$ western Siberia water bodies.

Towards filling the gap in our knowledge of seasonal variations of thermokarst lake chemical composition, we present in this work results of analysis of water and ice sampled in thermokarst lakes of various sizes, from several $\mathrm{m}$ to sev- eral $\mathrm{km}$ in diameter, during four main hydrological seasons: June, August, October and February. Our primary goal was to better understand the thermokarst lake biogeochemical functioning, which should allow us to constrain the impact of lake water metal and carbon cycling on river water composition and greenhouse gas exchange with the atmosphere in the course of a year. From a larger perspective, we aimed at the understanding of seasonal patterns of dissolved organic carbon and metal micronutrient concentrations in these shallow but highly abundant water bodies, different from previously studied glacial and deep thermokarst/yedoma lakes. This knowledge should allow predictions of phytoplankton activity, sedimentation and microbial respiration on the annual scale, necessary for evaluation of the net ecosystem exchange under various climate change scenarios. To this end, we addressed the following specific questions: (i) is there a statistically significant difference in major and trace element concentrations between different seasons, within a broad range of lake sizes? (ii) How significant is lake size and lake water residence time control for lake water chemical composition during different seasons? (iii) What are the mechanisms and degrees of element differentiation during ice formation and full water column freezing? (iv) How significant is water dilution during spring melt and what are the consequences for river water feeding by lakes during this period?

\section{Study site description, sampling, analytical and statistical methods}

Our study site is located in the central part of western Siberia $\left(63.5^{\circ} \mathrm{N}, 75.4^{\circ} \mathrm{E}\right.$, Nojabrsk administrative region) within the northern taiga geographical sub-zone (Fig. 1). It contains discontinous permafrost over the late Pleistocene sand and clay deposits that are covered by a layer of peat that is $1-2 \mathrm{~m}$ thick. All the lakes in this study are located at watershed divides between adjacent rivers. The water bodies ranged from a few $\mathrm{m}$ to several $\mathrm{km}$ in diameter and had a similar depth of $1.0 \pm 0.5 \mathrm{~m}$ under normal precipitation/evaporation conditions $(450 \mathrm{~mm})$. During dry summer, the lakes can decrease their depth twofold (Pokrovsky et al., 2013). The morphology, hydrology and water balance of thermokarst lakes have been extensively studied during four field campaigns in June, August, and October 2013 and February 2014. The detailed depth mapping of $\sim 20$ large lakes was performed via GPSechosounder from a rubber boat; the denivelation and the direction of the water flow were measured using a levelling network in several narrow profiles; the depth and density of snow were measured over a model site of $500 \mathrm{~m} \times 500 \mathrm{~m}$ that included lakes, a palsa bog, some streams and an adjacent forested riparian zone. The water residence time was calculated from the annual precipitation and evapotranspiration measured at the neighboring meteostation of the Russian Hydrometeorological Station, the annual runoff of the terri- 


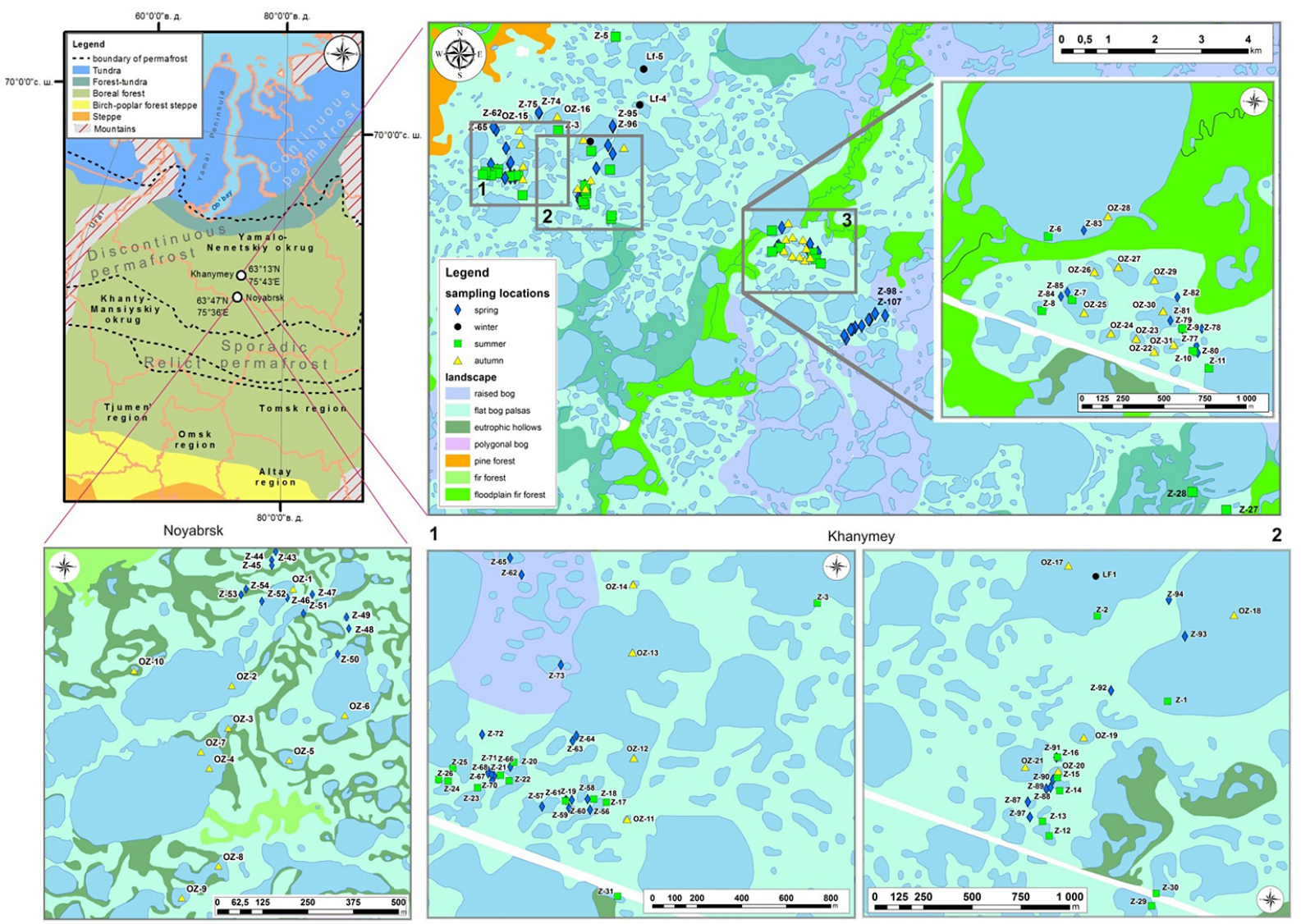

Figure 1. Study site area with symbols showing the position of sampled lakes and small water bodies in different seasons. Different colors correspond to different elementary ecosystems.

tory (between 200 and $250 \mathrm{~mm}$, Novikov, 2009, and Frey et al., 2007) and the water volume of the lakes measured on-site using a GPS-echosounder.

Water samples were collected from the PVC boat for large lakes or directly from the lake center for small $(<50 \mathrm{~m}$ diameter) water bodies (thaw ponds) during June and August 2013 and from the ice during the October 2013 and February 2014 sampling campaigns. A list of sampled water bodies and their main hydrological and hydrochemical characteristics is presented in Table 1. The sampling and filtration methods used in this study, as well as the chemical analysis techniques, are identical to those utilized in our previous studies (Pokrovsky et al., 2011). An ultraclean sampling procedure was used for all manipulations in the field (Shirokova et al., 2010). Water samples were filtered on-site through sterile single-use Minisart ${ }^{\circledR}$ filter units (Sartorius, acetate cellulose filters) with a pore size of $0.45 \mu \mathrm{m}$. For TE analysis, samples were acidified to $\mathrm{pH}=2$ with double-distilled $\mathrm{HNO}_{3}$. Dissolved oxygen, $\mathrm{pH}$, and Eh were measured on-site with uncertainties of $5 \%, 0.02$ units, and $2 \mathrm{mV}$, respectively, using a $\mathrm{WTW}^{\circledR}$ oximeter and a Hanna ${ }^{\circledR}$ portable $\mathrm{pH}$ meter with an $\mathrm{Eh} / \mathrm{pH}$ electrode.
Major anion concentrations $\left(\mathrm{Cl}^{-}\right.$and $\left.\mathrm{SO}_{4}^{2-}\right)$ were measured by ion chromatography (HPLC, Dionex ICS 2000) with an uncertainty of $2 \%$. DOC was analyzed using a Carbon Total Analyzer (Shimadzu TOC 6000) with an uncertainty lower than $3 \%$. Major and trace elements were determined with an ICP-MS Agilent ce 7500, routinely used in our laboratory for the analysis of samples from boreal organic-rich lakes (cf. Pokrovsky et al., 2013). Indium and rhenium were used as external standards. The international geostandard SLRS-5 (Riverine Water Reference Material for Trace Metals certified by the National Research Council of Canada) was used to check the accuracy and reproducibility of each analysis (Yeghicheyan et al., 2014). We obtained good agreement between replicate measurements of SLRS and certified values (relative difference $<10 \%$ SD for repeated measurements), except for B and P (30\%). While P was discarded for further analyses, B concentrations in most lakes are a factor of 3 to 7 higher than those in the SLSRS5 , and thus were retained. In addition to TE analysis using the Agilent quadropole instrument, $60 \%$ of samples were processed with an ultrasensitive Element XR ICP-MS instrument operated in a low and medium resolution mode. Using this ICP-MS greatly increased the detection limits of a num- 
Table 1. Major hydrophysical and hydrochemical parameters of studied lakes.

\begin{tabular}{|c|c|c|c|c|c|c|c|c|c|c|c|c|}
\hline & $\mathrm{N}$ & $\mathrm{E}$ & $S, \mathrm{~m}^{2}$ & $T,{ }^{\circ} \mathrm{C}$ & $\mathrm{O}_{2}, \mathrm{mgL}^{-1}$ & $\mathrm{O}_{2}, \%$ sat & $R, \mu \mathrm{Scm}^{-1}$ & $\mathrm{pH}$ & DIC, ppm & DOC, ppm & CI, ppm & $\mathrm{SO}_{4}, \mathrm{ppm}$ \\
\hline \multicolumn{13}{|l|}{ June } \\
\hline Z-43 & $63^{\circ} 13,580^{\prime}$ & $75^{\circ} 43,476^{\prime}$ & 1.8 & 6.5 & N.D. & N.D. & N.D. & 3.43 & 0.749 & 22.5 & 0.1532 & 0.9452 \\
\hline Z-44 & $63^{\circ} 13,567^{\prime}$ & $75^{\circ} 43,465^{\prime}$ & 0.071 & 7.5 & N.D. & N.D. & N.D. & 3.25 & 0.562 & 33.9 & 0.1458 & 0.9957 \\
\hline Z-45 & $63^{\circ} 13,559^{\prime}$ & $75^{\circ} 43,467^{\prime}$ & 4.9 & 6.0 & N.D. & N.D. & N.D. & 3.43 & 0.784 & 26.5 & 0.1466 & 0.8256 \\
\hline Z-46 & $63^{\circ} 13,513^{\prime}$ & $75^{\circ} 43,527^{\prime}$ & 31400 & 7.2 & N.D. & N.D. & N.D. & 3.28 & 0.396 & 13.6 & 0.0663 & 0.3680 \\
\hline Z-47 & $63^{\circ} 13,521^{\prime}$ & $75^{\circ} 43,608^{\prime}$ & 1.8 & 5.5 & N.D. & N.D. & N.D. & 3.51 & 0.598 & 23.6 & 0.0978 & 0.5896 \\
\hline Z-48 & $63^{\circ} 13,492^{\prime}$ & $75^{\circ} 43,726^{\prime}$ & 78.5 & 5.9 & N.D. & N.D. & N.D. & 3.49 & 0.433 & 17.2 & 0.0306 & 0.4516 \\
\hline Z-49 & $63^{\circ} 13,475^{\prime}$ & $75^{\circ} 43,737^{\prime}$ & 1.0 & 5.2 & N.D. & N.D. & N.D. & 3.37 & 0.545 & 22.1 & 0.1285 & 0.7087 \\
\hline $\mathrm{Z}-50$ & $63^{\circ} 13,436^{\prime}$ & $75^{\circ} 43,707^{\prime}$ & 96163 & 7.5 & N.D. & N.D. & N.D. & 3.77 & 0.550 & 6.5 & 0.0848 & 0.4372 \\
\hline Z-51 & $63^{\circ} 13,492^{\prime}$ & $75^{\circ} 43,584^{\prime}$ & 25434 & 7.2 & N.D. & N.D. & N.D. & 3.08 & 0.435 & 14.7 & 0.0131 & 0.448 \\
\hline Z-52 & $63^{\circ} 13,505^{\prime}$ & $75^{\circ} 43,444^{\prime}$ & 17663 & 6.6 & N.D. & N.D. & N.D. & 3.36 & 0.390 & 13.3 & 0.0678 & 0.369 \\
\hline Z-53 & $63^{\circ} 13,512^{\prime}$ & $75^{\circ} 43,374^{\prime}$ & 9.6 & 5.8 & N.D. & N.D. & N.D. & 3.47 & 0.447 & 17.4 & 0.0289 & 0.576 \\
\hline Z-54 & $63^{\circ} 13,521^{\prime}$ & $75^{\circ} 43,389^{\prime}$ & 0.13 & 5.5 & N.D. & N.D. & N.D. & 3.11 & 0.855 & 27.2 & 0.1337 & 0.752 \\
\hline Z-56 & $63^{\circ} 47^{\prime} 55.0^{\prime \prime}$ & $75^{\circ} 31^{\prime} 21.0^{\prime \prime}$ & 5671.6 & 3.8 & 9.1 & 86 & 12 & 4.2 & 0.431 & 14.1 & 0.1781 & 0.097 \\
\hline Z-57 & $63^{\circ} 47^{\prime} 54.4^{\prime \prime}$ & $75^{\circ} 31^{\prime} 6.55^{\prime \prime}$ & 3000 & 5.7 & 8.86 & 82 & 12 & 4.35 & 0.423 & 9.8 & 0.1637 & 0.616 \\
\hline Z-58 & $63^{\circ} 47^{\prime} 56.5^{\prime \prime}$ & $75^{\circ} 31^{\prime} 19.9^{\prime \prime}$ & 314 & 6.2 & 8.19 & 79 & 13 & 4.4 & 0.438 & 10.2 & 0.1616 & 0.595 \\
\hline Z-59 & $63^{\circ} 47^{\prime} 56.2^{\prime \prime}$ & $75^{\circ} 31^{\prime} 14.8^{\prime \prime}$ & 5024 & 6.0 & 8.3 & 77 & 30 & 4.5 & 0.437 & 24.9 & 0.0501 & 0.476 \\
\hline Z-60 & $63^{\circ} 47^{\prime} 55.0^{\prime \prime}$ & $75^{\circ} 31^{\prime} 14.1^{\prime \prime}$ & 314. & 6.6 & 8.23 & 78 & 21 & 4.0 & 0.459 & 15.2 & 0.0657 & 0.301 \\
\hline Z-61 & $63^{\circ} 47^{\prime} 56.1^{\prime \prime}$ & $75^{\circ} 31^{\prime} 12.9^{\prime \prime}$ & 176.6 & 6.5 & 8.2 & 77 & 17 & 4.05 & 0.410 & 12.5 & 0.0809 & 0.589 \\
\hline Z-62 & $63^{\circ} 48^{\prime} 28.0^{\prime \prime}$ & $75^{\circ} 30^{\prime} 52.1^{\prime \prime}$ & 1766250 & 5.9 & 8.25 & 79 & 12 & 4.2 & 0.477 & 13. & 0.2440 & 0.843 \\
\hline Z-63 & $63^{\circ} 48^{\prime} 04.7^{\prime \prime}$ & $75^{\circ} 31^{\prime} 13.4^{\prime \prime}$ & 28.3 & 8.5 & 7.33 & 74 & 20 & 4.5 & 0.394 & 24.5 & 0.024 & 0.233 \\
\hline Z-64 & $63^{\circ} 48^{\prime} 05.0^{\prime \prime}$ & $75^{\circ} 31^{\prime} 14.5^{\prime \prime}$ & 19.6 & 10.5 & 8.54 & 88 & 23 & 4.3 & 0.524 & 24.4 & 0.040 & 0.615 \\
\hline Z-65 & $63^{\circ} 48^{\prime} 29.5^{\prime \prime}$ & $75^{\circ} 30^{\prime} 50.5^{\prime \prime}$ & 11304 & 8.3 & 8.6 & 86 & 14 & 4.4 & 0.449 & 17.1 & 0.157 & 0.731 \\
\hline Z-66 & $63^{\circ} 48^{\prime} 00.2^{\prime \prime}$ & $75^{\circ} 30^{\prime} 53.8^{\prime \prime}$ & 314. & 9.9 & 8.55 & 85 & 15 & 4.8 & 0.429 & 12.6 & 0.064 & 0.964 \\
\hline Z-67 & $63^{\circ} 47^{\prime} 59.3^{\prime \prime}$ & $75^{\circ} 30^{\prime} 46.8^{\prime \prime}$ & 78.5 & 11.4 & 8.38 & 90 & 28 & 5.01 & 0.402 & 18.8 & 0.050 & 0.385 \\
\hline Z-68 & $63^{\circ} 47^{\prime} 59.0^{\prime \prime}$ & $75^{\circ} 30^{\prime} 46.8^{\prime \prime}$ & 176.6 & 10.2 & 8.46 & 88 & 22 & 4.4 & 0.378 & 16.9 & 0.043 & 0.725 \\
\hline Z-69 & $63^{\circ} 47^{\prime} 58.7^{\prime \prime}$ & $75^{\circ} 30^{\prime} 48.8^{\prime \prime}$ & 314. & 8.5 & 9.2 & 99 & 14 & 3.9 & 0.458 & 12.9 & 0.149 & 0.341 \\
\hline $\mathrm{Z}-70$ & $63^{\circ} 47^{\prime} 58.0^{\prime \prime}$ & $75^{\circ} 30^{\prime} 48.3^{\prime \prime}$ & 78.5 & 12.5 & 8.25 & 91 & 18 & 4.7 & 0.378 & 17.9 & 0.040 & 0.505 \\
\hline Z-71 & $63^{\circ} 47^{\prime} 58.9^{\prime \prime}$ & $75^{\circ} 30^{\prime} 47.9^{\prime \prime}$ & 0.0079 & N.D. & N.D. & N.D. & N.D. & N.D. & 0.610 & 22.6 & 1.484 & 0.843 \\
\hline Z-72 & $63^{\circ} 48^{\prime} 04.5^{\prime \prime}$ & $75^{\circ} 30^{\prime} 43.7^{\prime \prime}$ & 1.8 & 16.5 & 7.5 & 84 & 30 & 3.92 & 0.390 & 18.2 & 0.170 & 0.860 \\
\hline Z-73 & $63^{\circ} 48^{\prime} 15.5^{\prime \prime}$ & $75^{\circ} 31^{\prime} 07.4^{\prime \prime}$ & 706.5 & 12.9 & 8.7 & 98 & 17 & 3.8 & 0.372 & 12.8 & 0.069 & 0.339 \\
\hline $\mathrm{Z}-74^{* *}(\mathrm{~A})$ & $63^{\circ} 48^{\prime} 39.7^{\prime \prime}$ & $75^{\circ} 31^{\prime} 59.9^{\prime \prime}$ & 176625 & 6.3 & 9.2 & 94 & 9 & 4.0 & 0.426 & 7.8 & 0.146 & 0.647 \\
\hline Z-75 & $63^{\circ} 48^{\prime} 39.9^{\prime \prime}$ & $75^{\circ} 31^{\prime} 59.4^{\prime \prime}$ & 0.2 & 17.2 & 8.1 & 82 & 34 & 3.7 & 0.854 & 35.4 & 0.102 & 0.776 \\
\hline Z-77 & $63^{\circ} 46^{\prime} 58.0^{\prime \prime}$ & $75^{\circ} 39^{\prime} 12.2^{\prime \prime}$ & 113 & 12.4 & 7.95 & 87 & 32 & 4.4 & 0.432 & 27.5 & 0.102 & 0.247 \\
\hline Z-78 & $63^{\circ} 47^{\prime} 01.4^{\prime \prime}$ & $75^{\circ} 39^{\prime} 14.0^{\prime \prime}$ & 3.1 & 10.8 & 7.12 & 77 & 41 & 3.7 & 0.419 & 27.7 & 0.037 & 0.419 \\
\hline Z-79 & $63^{\circ} 47^{\prime} 01.0^{\prime \prime}$ & $75^{\circ} 39^{\prime} 05.4^{\prime \prime}$ & 314 & 12.7 & 7.6 & 86 & 18 & 3.5 & 0.304 & 18.3 & 0.022 & 0.201 \\
\hline Z-80 & $63^{\circ} 46^{\prime} 56.6^{\prime \prime}$ & $75^{\circ} 39^{\prime} 13.1^{\prime \prime}$ & 1256 & 11.8 & 7.8 & 85 & 23 & 3.3 & 0.303 & 19.4 & 0.093 & 0.276 \\
\hline Z-81 & $63^{\circ} 47^{\prime} 01.7^{\prime \prime}$ & $75^{\circ} 39^{\prime} 02.2^{\prime \prime}$ & 31400 & 12 & 8.3 & 93 & 19 & 4.0 & 0.323 & 15.8 & 0.304 & 0.163 \\
\hline Z-82 & $63^{\circ} 47^{\prime} 07.2^{\prime \prime}$ & $75^{\circ} 39^{\prime} 02.0^{\prime \prime}$ & 113 & 14.4 & 8.4 & 97 & 19 & 4.2 & 0.359 & 15.3 & 0.009 & 0.216 \\
\hline $\mathrm{Z}-83^{* *}(\mathrm{~B})$ & $63^{\circ} 47^{\prime} 18.9^{\prime \prime}$ & $75^{\circ} 38^{\prime} 30.1^{\prime \prime}$ & 1766250 & 3.4 & 8.6 & 82 & 11 & 4.6 & 0.858 & 6.5 & 0.117 & 0.209 \\
\hline Z-84 & $63^{\circ} 47^{\prime} 06.7^{\prime \prime}$ & $75^{\circ} 38^{\prime} 10.8^{\prime \prime}$ & 314 & 15.1 & 7.8 & 9 & 19 & 3.9 & 0.355 & 17.2 & 0.009 & 0.244 \\
\hline $\mathrm{Z}-85^{* *}(\mathrm{C})$ & $63^{\circ} 47^{\prime} 05.4^{\prime \prime}$ & $75^{\circ} 38^{\prime} 10.4^{\prime \prime}$ & 70650 & 1.9 & 7.99 & 8 & 7 & 4.6 & 0.433 & 5.5 & 0.067 & 0.471 \\
\hline Z-87 & $63^{\circ} 47^{\prime} 41.5^{\prime \prime}$ & $75^{\circ} 33^{\prime} 01.0^{\prime \prime}$ & 1256 & 13.7 & 8.43 & 95 & 12 & 4.5 & 0.338 & 11.6 & 0.060 & 0.493 \\
\hline Z-88 & $63^{\circ} 47^{\prime} 43.9^{\prime \prime}$ & $75^{\circ} 33^{\prime} 07.5^{\prime \prime}$ & 177 & 2.5 & 8.02 & 98 & N.D. & 4.6 & 0.325 & 17.9 & 0.031 & 0.260 \\
\hline Z-89 & $63^{\circ} 47^{\prime} 44.2^{\prime \prime}$ & $75^{\circ} 33^{\prime} 09.0^{\prime \prime}$ & 707 & N.D. & 7.4 & 98 & N.D. & N.D. & 0.285 & 9.7 & 0.189 & 0.215 \\
\hline $\mathrm{Z}-90^{* *}(\mathrm{D})$ & $63^{\circ} 47^{\prime} 45.5^{\prime \prime}$ & $75^{\circ} 33^{\prime} 09.7^{\prime \prime}$ & 159 & N.D. & 7.9 & 95 & N.D. & N.D. & 0.283 & 12.1 & 0.138 & 0.146 \\
\hline Z-91 & $63^{\circ} 47^{\prime} 49.2^{\prime \prime}$ & $75^{\circ} 33^{\prime} 10.3^{\prime \prime}$ & 380 & N.D. & 7.8 & 95 & 23 & 4.4 & 0.329 & 25.3 & 0.045 & 0.247 \\
\hline Z-92 & $63^{\circ} 48^{\prime} 01.0^{\prime \prime}$ & $75^{\circ} 33^{\prime} 28.5^{\prime \prime}$ & 78.5 & 20 & 7.7 & 95 & 12 & 4.7 & 0.334 & 16.6 & 0.014 & 0.255 \\
\hline Z-93**(E) & $63^{\circ} 48^{\prime} 11.0^{\prime \prime}$ & $75^{\circ} 33^{\prime} 54.4^{\prime \prime}$ & 2268650 & 16 & 8.36 & 99 & 9 & 4.8 & 0.402 & 18.5 & 0.245 & 0.756 \\
\hline Z-94 & $63^{\circ} 48^{\prime} 16.8^{\prime \prime}$ & $75^{\circ} 33^{\prime} 47.2^{\prime \prime}$ & 19.6 & 18 & 8.36 & 104 & 24 & 3.9 & 0.304 & 20.2 & 0.041 & 0.272 \\
\hline Z-95 & $63^{\circ} 48^{\prime} 29.7^{\prime \prime}$ & $75^{\circ} 33^{\prime} 55.0^{\prime \prime}$ & 4.9 & 17.8 & 7.4 & 98 & 31 & 4.1 & 0.305 & 26. & 0.045 & 0.732 \\
\hline Z-96* & $63^{\circ} 48^{\prime} 30.2^{\prime \prime}$ & $75^{\circ} 33^{\prime} 54.7^{\prime \prime}$ & 580586 & 9.3 & 7.9 & 88 & 8 & 4.7 & 0.550 & 8.6 & 0.166 & 1.011 \\
\hline Z-97 & $63^{\circ} 47^{\prime} 39.0^{\prime \prime}$ & $75^{\circ} 33^{\prime} 02.3^{\prime \prime}$ & 3 & 19.6 & 7.9 & 91 & 18 & 4.34 & 0.285 & 21.9 & 0.032 & 0.316 \\
\hline Z-98 & $63^{\circ} 46^{\prime} 17.2^{\prime \prime}$ & $75^{\circ} 40^{\prime} 58.6^{\prime \prime}$ & 0.79 & 15.6 & 7.27 & 92 & 19 & 4.5 & 0.282 & 20.7 & 0.108 & 0.317 \\
\hline Z-99 & $63^{\circ} 46^{\prime} 18.5^{\prime \prime}$ & $75^{\circ} 40^{\prime} 42.9^{\prime \prime}$ & 314 & 17.9 & 6.44 & 86 & N.D. & 4.45 & 0.298 & 20.3 & 0.136 & 0.027 \\
\hline $\mathrm{Z}-100$ & $63^{\circ} 46^{\prime} 14.4^{\prime \prime}$ & $75^{\circ} 40^{\prime} 34.2^{\prime \prime}$ & 3.1 & 15.7 & 6.7 & 84 & N.D. & 4.15 & 0.311 & 23.7 & 0.081 & 0.322 \\
\hline Z-101 & $63^{\circ} 46^{\prime} 14.4^{\prime \prime}$ & $75^{\circ} 40^{\prime} 32.5^{\prime \prime}$ & 785 & 13.3 & 6.8 & 8 & N.D. & 4.0 & 0.347 & 10. & 0.055 & 0.252 \\
\hline Z-102 & $63^{\circ} 46^{\prime} 10.1^{\prime \prime}$ & $75^{\circ} 40^{\prime} 21.5^{\prime \prime}$ & 4.9 & 12.5 & 5.7 & 7 & N.D. & 3.6 & 0.353 & 28.8 & 0.151 & 0.465 \\
\hline Z-103 & $63^{\circ} 46^{\prime} 09.2^{\prime \prime}$ & $75^{\circ} 40^{\prime} 11.4^{\prime \prime}$ & 961.6 & 19.5 & 6.8 & 88 & N.D. & 4.2 & 0.291 & 20.9 & 0.075 & 0.318 \\
\hline Z-104 & $63^{\circ} 46^{\prime} 07.8^{\prime \prime}$ & $75^{\circ} 40^{\prime} 07.0^{\prime \prime}$ & 0.13 & 17.9 & 5.3 & 71 & N.D. & 3.6 & 0.304 & 45. & 0.182 & 0.619 \\
\hline Z-105 & $63^{\circ} 46^{\prime} 07.7^{\prime \prime}$ & $75^{\circ} 40^{\prime} 04.4^{\prime \prime}$ & 706.5 & 14.6 & 6.7 & 80 & N.D. & 4.2 & 0.294 & 18.4 & 0.037 & 0.218 \\
\hline Z-106 & $63^{\circ} 46^{\prime} 01.4^{\prime \prime}$ & $75^{\circ} 39^{\prime} 57.0^{\prime \prime}$ & 12.6 & 18.2 & 6.8 & 90 & N.D. & 4.1 & 0.270 & 22.4 & 0.043 & 0.305 \\
\hline Z-107 & $63^{\circ} 46^{\prime} 03.7^{\prime \prime}$ & $75^{\circ} 39^{\prime} 54.3^{\prime \prime}$ & 196250 & 15.6 & 6.8 & 85 & N.D. & 4.31 & 0.293 & 25. & N.D.0 & N.D. \\
\hline
\end{tabular}


Table 1. Continued.

\begin{tabular}{|c|c|c|c|c|c|c|c|c|c|c|c|c|}
\hline & $\mathrm{N}$ & $\mathrm{E}$ & $S, \mathrm{~m}^{2}$ & $T,{ }^{\circ} \mathrm{C}$ & $\mathrm{O}_{2}, \mathrm{mgL}^{-1}$ & $\mathrm{O}_{2}, \%$ sat & $R, \mu \mathrm{S} \mathrm{cm}^{-1}$ & $\mathrm{pH}$ & DIC, ppm & $\mathrm{DOC}, \mathrm{ppm}$ & $\mathrm{Cl}, \mathrm{ppm}$ & $\mathrm{SO}_{4}, \mathrm{ppm}$ \\
\hline \multicolumn{13}{|l|}{ August } \\
\hline $\mathrm{Z}-1^{* *}(\mathrm{E})$ & $63^{\circ} 47^{\prime} 57.9^{\prime \prime}$ & $75^{\circ} 33^{\prime} 49.2^{\prime \prime}$ & 1200000 & N.D. & N.D. & N.D. & N.D. & 5.45 & 0.422 & 16.55 & 0.089 & 0.3259 \\
\hline $\mathrm{Z}-2^{*}$ & $63^{\circ} 48^{\prime} 11.1^{\prime \prime}$ & $75^{\circ} 33^{\prime} 23.2^{\prime \prime}$ & 580586 & N.D. & N.D. & N.D. & N.D. & 5.63 & 0.440 & 14.40 & 0.187 & 0.6155 \\
\hline $\mathrm{Z}-3^{* *}(\mathrm{~A})$ & $63^{\circ} 48^{\prime} 27.6^{\prime \prime}$ & $75^{\circ} 32^{\prime} 29.3^{\prime \prime}$ & 51300 & N.D. & N.D. & N.D. & N.D. & 4.88 & 0.376 & 13.86 & 0.111 & 0.2534 \\
\hline $\mathrm{Z}-4$ & $63^{\circ} 51^{\prime} 32.11^{\prime \prime}$ & $75^{\circ} 37^{\prime} 10.6^{\prime \prime}$ & 33000 & N.D. & N.D. & N.D. & N.D. & 4.88 & 0.363 & 7.73 & 0.039 & 0.0804 \\
\hline Z-5 & $63^{\circ} 49^{\prime} 32.1^{\prime \prime}$ & $75^{\circ} 34^{\prime} 00.6^{\prime \prime}$ & 74000 & N.D. & N.D. & N.D. & N.D. & 4.92 & 0.429 & 12.8 & 0.423 & 0.1880 \\
\hline Z-6**(B) & $63^{\circ} 47^{\prime} 15.2^{\prime \prime}$ & $75^{\circ} 37^{\prime} 58.3^{\prime \prime}$ & 138000 & N.D. & N.D. & N.D. & N.D. & 6.20 & 2.470 & 11.7 & 0.480 & 0.1711 \\
\hline $\mathrm{Z}-7^{* *}(\mathrm{C})$ & $63^{\circ} 47^{\prime} 06.7^{\prime \prime}$ & $75^{\circ} 38^{\prime} 12.2^{\prime \prime}$ & 60000 & N.D. & N.D. & N.D. & N.D. & 4.67 & 0.385 & 13.7 & 0.076 & 0.1023 \\
\hline $\mathrm{Z}-8$ & $63^{\circ} 47^{\prime} 02.3^{\prime \prime}$ & $75^{\circ} 38^{\prime} 02.5^{\prime \prime}$ & 6000 & N.D. & N.D. & N.D. & N.D. & 4.41 & 0.370 & 27.7 & 0.156 & 0.342 \\
\hline Z-9 & $63^{\circ} 47^{\prime} 01.1^{\prime \prime}$ & $75^{\circ} 39^{\prime} 05.5^{\prime \prime}$ & 359.8 & N.D. & N.D. & N.D. & N.D. & 4.20 & 0.403 & 27.4 & 0.098 & 0.200 \\
\hline Z-10 & $63^{\circ} 46^{\prime} 56.8^{\prime \prime}$ & $75^{\circ} 39^{\prime} 10.9^{\prime \prime}$ & 1481.9 & N.D. & N.D. & N.D. & N.D. & 4.21 & 0.334 & 51.8 & 0.197 & 0.326 \\
\hline Z-11 & $63^{\circ} 46^{\prime} 53.8^{\prime \prime}$ & $75^{\circ} 39^{\prime} 18.6^{\prime \prime}$ & 1766250 & N.D. & N.D. & N.D. & N.D. & 5.28 & 0.392 & 8.4 & 0.182 & 0.283 \\
\hline $\mathrm{Z}-12$ & $63^{\circ} 47^{\prime} 36.2^{\prime \prime}$ & $75^{\circ} 33^{\prime} 10.0^{\prime \prime}$ & 1256 & N.D. & N.D. & N.D. & N.D. & 4.66 & 0.392 & 11.6 & 0.048 & 0.104 \\
\hline Z-13 & $63^{\circ} 47^{\prime} 38.5^{\prime \prime}$ & $75^{\circ} 33^{\prime} 07.1^{\prime \prime}$ & 1963 & N.D. & N.D. & N.D. & N.D. & 4.16 & 0.570 & 35.4 & 0.090 & 0.306 \\
\hline Z-14 & $63^{\circ} 47^{\prime} 43.8^{\prime \prime}$ & $75^{\circ} 33^{\prime} 12.5^{\prime \prime}$ & 1963 & N.D. & N.D. & N.D. & N.D. & 4.33 & 0.310 & 18.5 & 0.037 & 0.114 \\
\hline $\mathrm{Z}-15^{* *}$ (D) & $63^{\circ} 47^{\prime} 45.9^{\prime \prime}$ & $75^{\circ} 33^{\prime} 11.2^{\prime \prime}$ & 1809 & N.D. & N.D. & N.D. & N.D. & 4.19 & 0.301 & 19.5 & 0.038 & 0.072 \\
\hline $\mathrm{Z}-16$ & $63^{\circ} 47^{\prime} 49.3^{\prime \prime}$ & $75^{\circ} 33^{\prime} 10.6^{\prime \prime}$ & 201.0 & N.D. & N.D. & N.D. & N.D. & 4.16 & 0.386 & 35.7 & 0.077 & 0.119 \\
\hline Z-17 & $63^{\circ} 47^{\prime} 56.3^{\prime \prime}$ & $75^{\circ} 31^{\prime} 26.1^{\prime \prime}$ & 2374.6 & N.D. & N.D. & N.D. & N.D. & 4.94 & 0.341 & 52.9 & 1.178 & 0.486 \\
\hline Z-18 & $63^{\circ} 47^{\prime} 56.6^{\prime \prime}$ & $75^{\circ} 31^{\prime} 21.9^{\prime \prime}$ & 707 & N.D. & N.D. & N.D. & N.D. & 4.35 & 0.373 & 17.6 & 0.082 & 0.049 \\
\hline Z-19 & $63^{\circ} 47^{\prime} 56.0^{\prime \prime}$ & $75^{\circ} 31^{\prime} 12.7^{\prime \prime}$ & 415 & N.D. & N.D. & N.D. & N.D. & 4.17 & 0.335 & 23.4 & 0.088 & 0.091 \\
\hline Z-20 & $63^{\circ} 48^{\prime} 00.9^{\prime \prime}$ & $75^{\circ} 30^{\prime} 54.8^{\prime \prime}$ & 78.5 & N.D. & N.D. & N.D. & N.D. & 4.65 & 0.306 & 38.6 & 0.242 & 0.159 \\
\hline $\mathrm{Z}-21$ & $63^{\circ} 47^{\prime} 58.9^{\prime \prime}$ & $75^{\circ} 30^{\prime} 50.8^{\prime \prime}$ & 491 & N.D. & N.D. & N.D. & N.D. & 4.50 & 0.319 & 35.6 & 0.118 & 0.245 \\
\hline Z-22 & $63^{\circ} 47^{\prime} 58.2^{\prime \prime}$ & $75^{\circ} 30^{\prime} 53.8^{\prime \prime}$ & 7850 & N.D. & N.D. & N.D. & N.D. & 4.25 & 0.316 & 31.0 & 0.157 & 3.115 \\
\hline Z-23 & $63^{\circ} 47^{\prime} 56.8^{\prime \prime}$ & $75^{\circ} 30^{\prime} 43.7^{\prime \prime}$ & 4416 & N.D. & N.D. & N.D. & N.D. & 4.56 & 0.300 & 28.7 & 0.084 & 3.116 \\
\hline Z-24 & $63^{\circ} 47^{\prime} 57.4^{\prime \prime}$ & $75^{\circ} 30^{\prime} 33.9^{\prime \prime}$ & 6359 & N.D. & N.D. & N.D. & N.D. & 4.35 & 0.321 & 18.9 & 0.142 & 0.126 \\
\hline $\mathrm{Z}-25$ & $63^{\circ} 47^{\prime} 59.3^{\prime \prime}$ & $75^{\circ} 30^{\prime} 35.1^{\prime \prime}$ & 5408 & N.D. & N.D. & N.D. & N.D. & 4.88 & 0.312 & 18.6 & 0.073 & 0.164 \\
\hline Z-26 & $63^{\circ} 47^{\prime} 57.5^{\prime \prime}$ & $75^{\circ} 30^{\prime} 30.8^{\prime \prime}$ & 314 & N.D. & N.D. & N.D. & N.D. & 4.48 & 0.340 & 54.7 & 0.193 & 0.280 \\
\hline $\mathrm{Z}-27$ & $63^{\circ} 43^{\prime} 59.9^{\prime \prime}$ & $75^{\circ} 49^{\prime} 48.3^{\prime \prime}$ & 2375 & N.D. & N.D. & N.D. & N.D. & 5.88 & 0.865 & 9.3 & 0.031 & 2.016 \\
\hline Z-28 & $63^{\circ} 44^{\prime} 12.7^{\prime \prime}$ & $75^{\circ} 48^{\prime} 55.6^{\prime \prime}$ & 3524 & N.D. & N.D. & N.D. & N.D. & 6.10 & 1.251 & 15.3 & 0.197 & 0.183 \\
\hline Z-29 & $63^{\circ} 47^{\prime} 26.1^{\prime \prime}$ & $75^{\circ} 33^{\prime} 50.5^{\prime \prime}$ & 152 & N.D. & N.D. & N.D. & N.D. & 5.54 & 0.465 & 22.8 & 0.766 & 0.246 \\
\hline Z-30 & $63^{\circ} 47^{\prime} 28.2^{\prime \prime}$ & $75^{\circ} 33^{\prime} 51.8^{\prime \prime}$ & 31400 & N.D. & N.D. & N.D. & N.D. & 5.59 & 0.360 & 38.2 & 0.608 & 4.797 \\
\hline $\mathrm{Z}-31$ & $63^{\circ} 47^{\prime} 42.9^{\prime \prime}$ & $75^{\circ} 31^{\prime} 32.4^{\prime \prime}$ & 5024 & N.D. & N.D. & N.D. & N.D. & 5.66 & 0.357 & 10.6 & 0.55 & 0.855 \\
\hline \multicolumn{13}{|l|}{ October } \\
\hline OZ-1 & $63^{\circ} 13^{\prime} 31.6^{\prime \prime}$ & $75^{\circ} 43^{\prime} 32.6^{\prime \prime}$ & 96163 & N.D. & N.D. & N.D. & N.D. & 4.21 & 1.552 & 48.2 & 0.181 & 0.110 \\
\hline OZ-2 & $63^{\circ} 13^{\prime} 22.6^{\prime \prime}$ & $75^{\circ} 43^{\prime} 22.1^{\prime \prime}$ & 17663 & N.D. & N.D. & N.D. & N.D. & 4.57 & 0.713 & 32.1 & 0.183 & 0.379 \\
\hline OZ-3 & $63^{\circ} 13^{\prime} 18.8^{\prime \prime}$ & $75^{\circ} 43^{\prime} 22.1^{\prime \prime}$ & 491 & N.D. & N.D. & N.D. & N.D. & 5.29 & 1.835 & 52.7 & 0.282 & 0.232 \\
\hline OZ-4 & $63^{\circ} 13^{\prime} 15.1^{\prime \prime}$ & $75^{\circ} 43^{\prime} 19.0^{\prime \prime}$ & 70650 & N.D. & N.D. & N.D. & N.D. & 4.69 & 0.618 & 12.3 & 0.128 & 0.153 \\
\hline OZ-5 & $63^{\circ} 13^{\prime} 16.4^{\prime \prime}$ & $75^{\circ} 43^{\prime} 34.6^{\prime \prime}$ & 1963 & N.D. & N.D. & N.D. & N.D. & 3.75 & 0.536 & 27.5 & 0.115 & 0.128 \\
\hline OZ-6 & $63^{\circ} 13^{\prime} 20.8^{\prime \prime}$ & $75^{\circ} 43^{\prime} 44.8^{\prime \prime}$ & 12266 & N.D. & N.D. & N.D. & N.D. & 4.29 & 0.445 & 14.1 & 0.078 & 0.133 \\
\hline OZ-7 & $63^{\circ} 13^{\prime} 16.5^{\prime \prime}$ & $75^{\circ} 43^{\prime} 17.1^{\prime \prime}$ & 49063 & N.D. & N.D. & N.D. & N.D. & 4.99 & 0.533 & 13.5 & 0.129 & 0.164 \\
\hline OZ-8 & $63^{\circ} 13^{\prime} 06.5^{\prime \prime}$ & $75^{\circ} 43^{\prime} 22.4^{\prime \prime}$ & 707 & N.D. & N.D. & N.D. & N.D. & 4.74 & 1.828 & 39.1 & 0.309 & 0.308 \\
\hline OZ-9 & $63^{\circ} 13^{\prime} 03.4^{\prime \prime}$ & $75^{\circ} 43^{\prime} 15.7^{\prime \prime}$ & 2826 & N.D. & N.D. & N.D. & N.D. & 4.33 & 0.488 & 17.0 & 0.106 & 0.037 \\
\hline OZ-10 & $63^{\circ} 13^{\prime} 23.2^{\prime \prime}$ & $75^{\circ} 43^{\prime} 02.6^{\prime \prime}$ & 177 & N.D. & N.D. & N.D. & N.D. & 4.52 & 3.492 & 35.4 & 1.252 & 0.178 \\
\hline OZ-11 & $63^{\circ} 47^{\prime} 54.1^{\prime \prime}$ & $75^{\circ} 31^{\prime} 33.3^{\prime \prime}$ & 110 & N.D. & N.D. & N.D. & N.D. & 3.99 & 0.723 & 24.3 & 0.541 & 0.036 \\
\hline OZ-12 & $63^{\circ} 48^{\prime} 03.0^{\prime \prime}$ & $75^{\circ} 31^{\prime} 33.8^{\prime \prime}$ & 196250 & N.D. & 9.3 & 86 & N.D. & 4.57 & 1.264 & 29.2 & 0.201 & 0.746 \\
\hline OZ-13 & $63^{\circ} 48^{\prime} 18.2^{\prime \prime}$ & $75^{\circ} 31^{\prime} 30.4^{\prime \prime}$ & 196250 & N.D. & $10.5 / 8.3$ & $95 / 74$ & 8 & 4.77 & 0.574 & 24.3 & 0.165 & 0.601 \\
\hline OZ-14 & $63^{\circ} 48^{\prime} 28.0^{\prime \prime}$ & $75^{\circ} 31^{\prime} 28.7^{\prime \prime}$ & 707 & N.D. & $12.3 / 1$ & $100 / 94$ & 6 & 4.21 & 0.460 & 16.8 & 0.122 & 0.060 \\
\hline OZ-15 & $63^{\circ} 48^{\prime} 36.8^{\prime \prime}$ & $75^{\circ} 31^{\prime} 38.1^{\prime \prime}$ & 41527 & N.D. & $8.8 / 7.2$ & $74 / 64$ & N.D. & 4.84 & 0.650 & 26.3 & 0.224 & 0.248 \\
\hline $\mathrm{OZ}-16^{* *}(\mathrm{~A})$ & $63^{\circ} 48^{\prime} 37.3^{\prime \prime}$ & $75^{\circ} 32^{\prime} 28.2^{\prime \prime}$ & 503300 & N.D. & $7.4 / 6.2$ & $67 / 56$ & N.D. & 4.87 & 0.581 & 13.7 & 0.194 & 0.314 \\
\hline OZ-17* & $63^{\circ} 48^{\prime} 21.0^{\prime \prime}$ & $75^{\circ} 33^{\prime} 08.6^{\prime \prime}$ & 580586 & N.D. & $9.1 / 6.9$ & $8 / 66$ & N.D. & 5.01 & 0.507 & 15.3 & 0.284 & 0.316 \\
\hline OZ-18** $(\mathrm{E})$ & $63^{\circ} 48^{\prime} 15.2^{\prime \prime}$ & $75^{\circ} 34^{\prime} 12.0^{\prime \prime}$ & 1207000 & N.D. & $8.1 / 7.3$ & $8 / 68$ & N.D. & 4.69 & 0.495 & 13.7 & 0.193 & 0.708 \\
\hline OZ-19 & $63^{\circ} 47^{\prime} 52.9^{\prime \prime}$ & $75^{\circ} 33^{\prime} 19.8^{\prime \prime}$ & 9499 & N.D. & $8.6 / 5.8$ & $78 / 55.2$ & N.D. & 4.10 & 0.602 & 29.6 & 0.074 & 0.247 \\
\hline OZ-20**(D) & $63^{\circ} 47^{\prime} 47.0^{\prime \prime}$ & $75^{\circ} 33^{\prime} 11.3^{\prime \prime}$ & 3485 & N.D. & $11.7 / 10.3$ & $101 / 97$ & N.D. & 4.01 & 0.596 & 24.9 & 0.179 & 0.052 \\
\hline OZ-21 & $63^{\circ} 47^{\prime} 47.2^{\prime \prime}$ & $75^{\circ} 32^{\prime} 58.9^{\prime \prime}$ & 11304 & N.D. & $10.1 / 4.7$ & $92 / 44$ & N.D. & 4.91 & 0.530 & 45.6 & 0.464 & 1.410 \\
\hline OZ-22 & $63^{\circ} 46^{\prime} 56.1^{\prime \prime}$ & $75^{\circ} 38^{\prime} 53.7^{\prime \prime}$ & 2462 & N.D. & $8.25 / 5.87$ & $72 / 53$ & N.D. & 3.96 & 0.508 & 28.6 & 0.246 & 1.566 \\
\hline $\mathrm{OZ}-23$ & $63^{\circ} 46^{\prime} 58.4^{\prime \prime}$ & $75^{\circ} 38^{\prime} 45.2^{\prime \prime}$ & 5024 & N.D. & $4.2 / 3.34$ & $38 / 30$ & N.D. & 3.81 & 0.662 & 27.7 & 0.828 & 0.878 \\
\hline OZ-24 & $63^{\circ} 46^{\prime} 59.0^{\prime \prime}$ & $75^{\circ} 38^{\prime} 33.8^{\prime \prime}$ & 3215 & N.D. & $5.1 / 4.5$ & $46 / 40$ & N.D. & 3.99 & 0.595 & 16.5 & 0.140 & 0.121 \\
\hline $\mathrm{OZ}-25^{* *}(\mathrm{C})$ & $63^{\circ} 47^{\prime} 02.6^{\prime \prime}$ & $75^{\circ} 38^{\prime} 21.2^{\prime \prime}$ & 53630 & N.D. & $9.2 / 4.4$ & $85 / 41$ & N.D. & 4.06 & 0.556 & 16.3 & 0.095 & 0.204 \\
\hline OZ-26 & $63^{\circ} 47^{\prime} 1.8^{\prime \prime}$ & $75^{\circ} 38^{\prime} 24.2^{\prime \prime}$ & 5672 & N.D. & $8.3 / 4$ & $75 / 38$ & N.D. & 4.85 & 0.820 & 31.1 & 0.234 & 2.909 \\
\hline OZ-27 & $63^{\circ} 47^{\prime} 12.1^{\prime \prime}$ & $75^{\circ} 38^{\prime} 34.64^{\prime \prime}$ & 17663 & N.D. & $7.8 / 5.4$ & $79 / 49$ & N.D. & 3.87 & 0.466 & 33.1 & 0.164 & 0.535 \\
\hline $\mathrm{OZ}-28^{* *}(\mathrm{~B})$ & $63^{\circ} 47^{\prime} 21.9^{\prime \prime}$ & $75^{\circ} 38^{\prime} 28.2^{\prime \prime}$ & 1396000 & N.D. & 9.75 & 87 & N.D. & 6.90 & 2.920 & 12.3 & 0.543 & 1.686 \\
\hline OZ-29 & $67^{\circ} 47^{\prime} 1.2^{\prime \prime}$ & $75^{\circ} 38^{\prime} 51.1^{\prime \prime}$ & 28339 & N.D. & $4.2 / 5.4$ & $37 / 49$ & N.D. & 3.98 & 0.488 & 37.5 & 0.170 & 0.606 \\
\hline OZ-30 & $63^{\circ} 47^{\prime} 04.2^{\prime \prime}$ & $75^{\circ} 38^{\prime} 56.1^{\prime \prime}$ & 13267 & N.D. & $4.2 / 5.8$ & $37 / 51$ & N.D. & 3.98 & 0.444 & 34.4 & 0.187 & 0.669 \\
\hline OZ-31 & $63^{\circ} 46^{\prime} 57.8^{\prime \prime}$ & $75^{\circ} 39^{\prime} 02.1^{\prime \prime}$ & 962 & N.D. & $4.5 / 3.9$ & $4 / 35$ & N.D. & 3.77 & 0.469 & 23.1 & 0.229 & 0.186 \\
\hline \multicolumn{13}{|l|}{ February } \\
\hline LF1 bottom & $63^{\circ} 48^{\prime} 19.6^{\prime \prime}$ & $75^{\circ} 33^{\prime} 19.2^{\prime \prime}$ & 580586 & N.D. & N.D. & N.D. & N.D. & N.D. & 0.496 & 30.3 & 0.792 & 3.440 \\
\hline LF4 bottom & $63^{\circ} 48^{\prime} 44.7^{\prime \prime}$ & $75^{\circ} 34^{\prime} 37.3^{\prime \prime}$ & 351335 & N.D. & N.D. & N.D. & 19 & 4.655 & 0.778 & 19.0 & 0.235 & 1.678 \\
\hline LFS bottom & $63^{\circ} 49^{\prime} 09.4^{\prime \prime}$ & $75^{\circ} 34^{\prime} 44.1^{\prime \prime}$ & 1743000 & N.D. & N.D. & N.D. & 31 & 4.778 & 1.022 & 32.9 & 0.281 & 2.973 \\
\hline
\end{tabular}


ber of elements and improved the precision of the analyses while avoiding interferences. The uncertainty of the Element XR analysis was $\leq 5 \%$, while its detection limit was a factor of 100 lower than the traditional (Agilent) instrument. The average agreement between the two ICP-MS instruments for the majority of the TE was $10-15 \%$.

The lake ice was sampled in February 2014 from the central part of the lakes using titanium circular ice coring. The ice core was cut using a Ti saw into $10 \mathrm{~cm}$ slices, melted at room temperature and immediately filtered through $0.45 \mu \mathrm{m}$ filters. Before and after fieldwork, blank samples were run by filling the pre-cleaned PVC container with MilliQ water and submerged $\mathrm{Ti}$ blades at neutral $\mathrm{pH}$, and leaving it to react for several hours. No detectable contamination of Ti or any major and trace elements was observed. The ice filtrate was processed in the same way as the lake water. In three lakes (out of $\sim$ ten studied in February), the bottom layer of unfrozen water below the ice column was collected for analysis. Chemical composition of Fe-rich coagulates collected from the ice surface in early June was measured by ICP-MS after full dissolution of the solid using a microwave acid digestion procedure (Stepanova et al., 2014). Particulate organic carbon was quantified using the $\mathrm{TOC}_{\mathrm{CHS}}$ instrument. The freeze-dried precipitates were characterized by scanning electron microscopy (SEM) using a Jeol JSM840a, and by $\mathrm{X}$-ray diffraction using an INEL CPS $120 \mathrm{CoK} \alpha$.

The element concentrations were analyzed using best fit functions based on the least squares method, Pearson correlation and one-way ANOVA (SigmaPlot version 11.0/Systat Software, Inc). Regressions and power functions were used to examine the relationships between the elemental concentrations and the lake surface areas. The ANOVA was carried out using Dunn's method because each sampling period contained a different number of water bodies. Principal component analysis (PCA) was used for the ensemble of sampled lakes and for each season individually, to reduce the number of variables and to detect the structure in the relationships between the elements. The data consisted of $\sim 130$ lake water samples grouped into three distinct seasons (spring, summer and autumn). Statistical PCA analyses were applied in order to derive a distinctive view of the influence of various parameters, notably the seasons, on the lake water chemical composition variability. Both normed and non-normed PCA treatment was attempted. Statistical analysis considered each chemical element as a variable (35 in total) for all lakes. For this step, the STATISTICA package (http://www.statsoft.com), which is also designed to compute and render graphics, was used to interpret the spatial structures.

\section{Results}

\subsection{Effect of the lake size on dissolved carbon and related elements concentration in the water column}

The list of sampled water bodies with their main hydrophysical and hydrochemical characteristics and their geographical localization are given in Table 1 and Fig. 1, respectively. Within the range of 100 to $2 \times 10^{6} \mathrm{~m}^{2}$ lake size, the effect of lake size on major and trace element concentration is not strongly pronounced. The correlation coefficient was below 0.5 for all elements over all seasons, suggesting a quite weak if not negligible impact of the lake size on lake water chemical composition (Table S1 of the Supplement).

The highly variable number of sampled lakes during each season was basically due to the difficulties in sampling logistics and the access to the site. Only five lakes (labeled A, B, C, D and E in Table 1) could be collected during all three open water seasons. In winter, we could not sample more than three lakes (both ice core and bottom water). All small lakes $\left(<1000 \mathrm{~m}^{2}\right)$ were frozen solid in October (autumn period). We did not focus in this work on small-size $\left(<500 \mathrm{~m}^{2}\right)$ lakes in summer, because the small water objects were thoroughly studied in our previous work (Shirokova et al., 2013). Besides, many small ponds $\left(10-100 \mathrm{~m}^{2}\right)$ were dried in $\mathrm{Au}$ gust 2013. For this reason, the size range of the sampled lakes is different among seasons.

Only in spring, for the range of 0.1 to $2 \times 10^{6} \mathrm{~m}^{2}$ lake size, was Pearson's coefficient statistically significant $(p<0.05)$ and suggested a decrease in the following element concentration with the logarithm of the lake size increase: DOC $(-0.69), \mathrm{V}(-0.43), \mathrm{Cr}(-0.54), \mathrm{Ni}(-0.58), \mathrm{Cu}(-0.63)$, $\mathrm{Ga}(-0.71)$, As (-0.53), Cd (-0.69), and Pb (-0.8). Such a semi-logarithmic negative relationship suggests a rapid decrease in the concentration within the small water bodies and its relative stability in large lakes. Indeed, this trend was mainly due to the increase in certain element concentrations in the smallest $\left(<10-100 \mathrm{~m}^{2}\right)$ water bodies rather than a steady evolution of concentrations in medium-size and large water bodies.

The DOC concentration exhibited two maxima, at 1000$10000 \mathrm{~m}^{2}$ surface area in summer and autumn and in microdepressions $\left(<1 \mathrm{~m}^{2}\right)$ in spring (Fig. 2). The nature of the DOC was different among different seasons, because the slope of the $\mathrm{UV}_{280}$ - [DOC] dependence increased in the order spring $(0.024)<\operatorname{summer}(0.030)<$ autumn $(0.035)<$ winter (0.0354). The ratio of $\mathrm{UV}_{280}$ to [DOC] during four sampled seasons demonstrated the lowest values in spring and the highest in autumn-winter, being independent of the lake size (Fig. 3).

None of the seasons demonstrated a statistically significant dependence between the element concentration and the water body size above $100 \mathrm{~m}^{2}(p>0.05)$. There was quite high variability in the major element concentration in lakes of the same size range, typically over 2 orders of magnitude, as can 


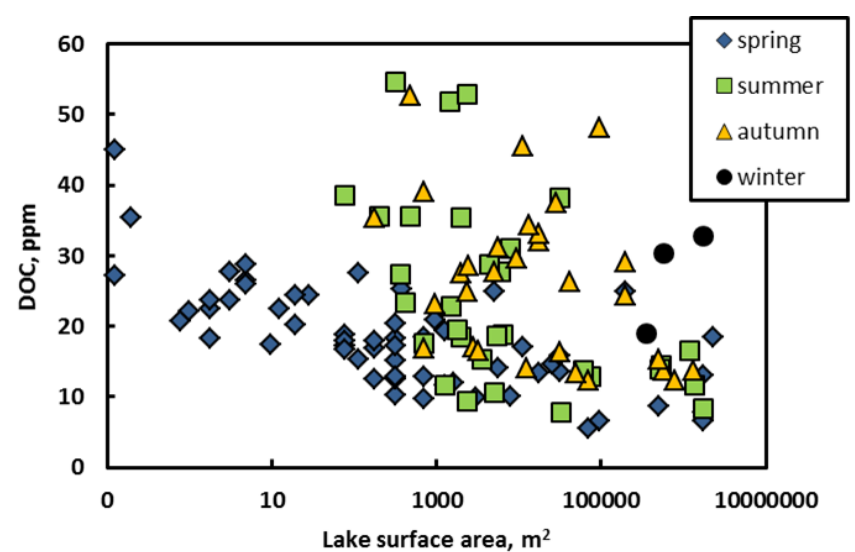

Figure 2. DOC concentration in thermokarst lakes of various sizes during four observation seasons.

be seen for $\mathrm{Ca}$ and $\mathrm{Si}$ in Fig. S2a and b in the Supplement, respectively. There was a general increase in the lake water $\mathrm{pH}$ with the increase in the lake size (statistically significant at $p<0.05$ ), most visible during summer (Fig. 4). The small-size lakes sampled in spring exhibited the lowest $\mathrm{pH}$, between 3.5 and 4.5 , whereas the larger lakes $\left(>1000 \mathrm{~m}^{2}\right)$ in summer demonstrated a $\mathrm{pH}$ of 5 to 6 . Similar to major cations, the major anion concentration did not demonstrate any discernable trend $(p>0.05)$ with the lake surface area; only $\mathrm{Cl}^{-}$yielded the minimal concentration for the lakes of ca. $100 \mathrm{~m}^{2}$ surface area. Dissolved inorganic carbon (DIC) concentration was a factor of 30 lower than [DOC], without a statistically significant trend with the lake size (not shown). The illustration of the lake surface area effect on trace element concentration during all four sampled seasons is given in Fig. S3 for Fe, Al, Mn, Zn, Cu, Pb, Mo, V, As and Sb, and the primary data are listed in Table $\mathrm{S} 2$.

There was a limited degree of element correlation with either DOC or Fe considering all seasons of the year, as follows from Pearson pair correlation (Table S3). Examples of mostly pronounced correlations between $\mathrm{Fe}$ and DOC, As and $\mathrm{Fe}$, and $\mathrm{Cd}$ and DOC are illustrated in Fig. S4.

The statistical treatment of the data did not reveal significant $(p>0.05)$ links between TE concentration and UV280 nm. Rather poor correlations shown in Fig. S4 of the manuscript are illustrative for both UV and DOC. The concentration of TE in peat unfrozen horizon and in ground vegetation (green and brown mosses) in the discontinuous permafrost zone of western Siberia are rather similar (Stepanova et al., 2015). As a result, $\mathrm{UV}_{280}$ can help to distinguish between the element leaching from vegetation as opposed to peat leaching. Rather, the similarity of specific UV absorbances across the seasons and lake sizes strongly suggests the dominance of terrestrial (soil and litter) sources of OC with minimal aquagenic DOM.

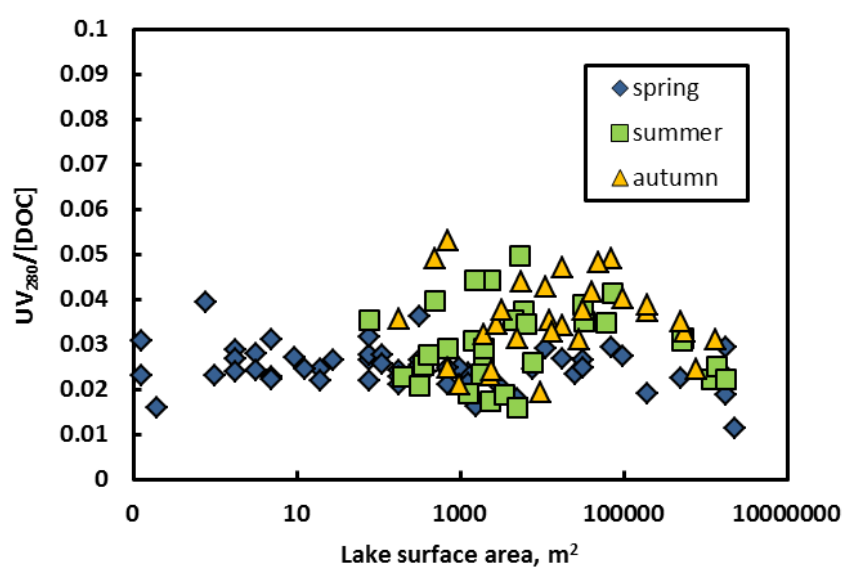

Figure 3. UV absorbance properties of thermokarst lake waters. The $\mathrm{UV}_{280} / \mathrm{DOC}$ ratio increases in the order spring < summer $<$ autumn, suggesting the progressive increase in aromaticity that is independent of the lake size $(p>0.05)$. The average values of $\mathrm{UV}_{280 \mathrm{~nm}} /$ [DOC] are equal to $0.024 \pm 0.0037,0.030 \pm 0.0072$, $0.035 \pm 0.0069$, and $0.0354 \pm 0.0068 \mathrm{~L} \mathrm{mg}^{-1} \mathrm{~cm}^{-1}$ in spring, summer, autumn and winter, respectively.

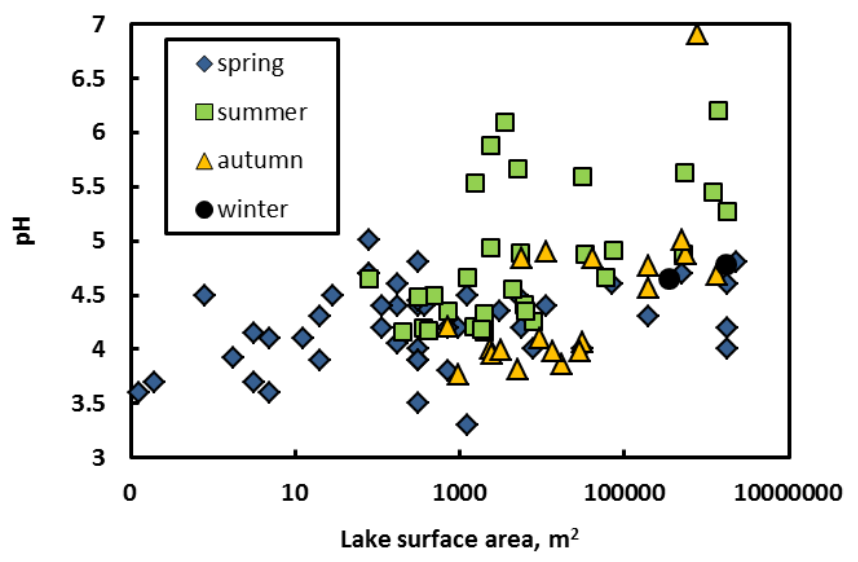

Figure 4. Increase in lake water $\mathrm{pH}$ with the increase in the lake size over four studied seasons. Note that the lowest $\mathrm{pH}$ is observed in spring and is highest in summer. This likely reflects the dominance of allochthonous organic input in the lake in spring, notably in the smallest water bodies, and autochthonous processes of some phytoplankton and macrophyte activity at the end of the summer.

Considering all seasons simultaneously, several groups of elements could be distinguished based on this correlation analysis:

1. elements correlated with $\mathrm{Fe}\left(R_{F e}>R_{D O C}\right): \mathrm{Cl}, \mathrm{SO}_{4}$, $\mathrm{Mg}, \mathrm{Ca}, \mathrm{Sr}, \mathrm{Ba}, \mathrm{Rb}, \mathrm{Al}, \mathrm{Ga}, \mathrm{Cr}, \mathrm{Mn}, \mathrm{Co}, \mathrm{Ni}, \mathrm{Si}, \mathrm{As}$, REEs and $\mathrm{U}$,

2. elements correlated with DOC rather than with $\mathrm{Fe}$ $\left(R_{D O C}>R_{F e}\right): \mathrm{Cu}, \mathrm{Zn}, \mathrm{Cd}$ and $\mathrm{Pb}$, 
3. elements strongly correlated with $\mathrm{Al}(\mathrm{R}>0.6$ at $p<0.05)$ : $\mathrm{Be}, \mathrm{Si}, \mathrm{K}, \mathrm{Rb}, \mathrm{Cs}, \mathrm{Sr}, \mathrm{Ba}, \mathrm{Ti}, \mathrm{V}, \mathrm{Cr}, \mathrm{Co}, \mathrm{Cu}$, $\mathrm{Ga}, \mathrm{As}, \mathrm{Sb}$, REEs, $\mathrm{W}$ and $\mathrm{U}$, and

4. elements exhibiting high pair correlations $(\mathrm{R} \geq 0.9$ at $p<0.05)$ : Ga-Al, Cr-Al, Hf-Th.

Note that all elements exhibited better inter-correlations in spring compared to other seasons (Table S3).

\subsection{Lake freezing during the glacial period (October to the end of May) and ice-layered structure formation}

Observations during the beginning of the ice formation (October 2013) yielded important and novel features of the thermokarst lake ice cover evolution during the glacial period. Given the closed basins of all sampled lakes underlain by permafrost without a connection to the groundwater source (i.e., Pokrovsky et al., 2011, 2014), the water was expected to be under excess pressure under the ice. This was confirmed by direct observations in October: the water always rose upward and spread over the ice surface after drilling the first $10-20 \mathrm{~cm}$ of the ice layer. Upon the thickening of the ice, cracks formed on the ice cover and the water from the deeper layers seeped and spread over the ice surface, thus forming organic- and Fe-rich multilayered ice up to $30 \mathrm{~cm}$ thick. The wind acting on still unfrozen freshly ejected water created ice ripples spreading over a surface of $10-50 \mathrm{~m}^{2}$ (Fig. S5). The full freezing of ejected organic-rich water led to browning of the ice and presumably produced significant coagulation of colloids. The products of this coagulation could be notably seen at the end of the spring, during massive ice melt (Fig. S6).

In situ oxygen analysis with a submersible $\mathrm{O}_{2}$ sensor in June and August demonstrates saturation with atmospheric oxygen close to $90 \pm 10 \%$ (Table 1). In October, under the ice, we found only $40-80 \%$ saturation of the water layer, with some redox stratification within 20 and $50 \mathrm{~cm}$ of the unfrozen water column. There was a $50 \%$ drop in $\mathrm{O}_{2}$ concentration at the sediment-water interface relative to the bottom of the ice core. Generally, the smaller the water body, the lower the oxygen concentration, although a straightforward relation between the size of the lake and the oxygen saturation in October could not be established $(p>0.05)$.

The ice core analysis with the resolution of $5-10 \mathrm{~cm}$ demonstrated either an enrichment of the surface ice layers in dissolved elements, or their non-systematic variation over the full depth of the ice core (Table S4). The enrichment, by a factor of 2 to 5 , of the first $0-30 \pm 10 \mathrm{~cm}$ was detected for DOC and most metals such as $\mathrm{Al}, \mathrm{Fe}, \mathrm{Ni}, \mathrm{Co}, \mathrm{Cu}, \mathrm{Zn}$ and $\mathrm{Pb}$, as illustrated for selected metals in Fig. 5. Manganese demonstrated the largest variation along the ice core depth. Its concentration decreased from 3 to $10 \mathrm{ppb}$ at the very surface down to less than $0.1 \mathrm{ppb}$ below $50 \mathrm{~cm}$. In contrast, many trace elements (Cd, Cs, Sb, Ti, Zr, Hf, Th, U, REEs) did
Table 2. Distribution coefficient of soluble components between the lake water and the ice (average of three samples). The lower part of the ice column, formed in quasi-equilibrium with the remaining bottom water, was used for this estimation.

\begin{tabular}{lr}
\hline Element & $K_{\mathrm{d}}$ (water)/(ice) \\
\hline $\mathrm{DIC}$ & $1.64 \pm 0.37$ \\
$\mathrm{DOC}$ & $10.3 \pm 7.0$ \\
$\mathrm{Cl}^{-}$ & $7.58 \pm 3.0$ \\
$\mathrm{SO}_{4}$ & $44.1 \pm 10.9$ \\
$\mathrm{Na}$ & $21.2 \pm 3.4$ \\
$\mathrm{Mg}$ & $17.9 \pm 5.4$ \\
$\mathrm{Al}$ & $93.1 \pm 32.9$ \\
$\mathrm{Si}$ & $12.4 \pm 5.2$ \\
$\mathrm{~K}$ & $45.8 \pm 24.1$ \\
$\mathrm{Ca}$ & $10.2 \pm 5.2$ \\
$\mathrm{Ti}$ & $50 \pm 20$ \\
$\mathrm{~V}$ & $22.9 \pm 3.5$ \\
$\mathrm{Cr}$ & $20.7 \pm 8.9$ \\
$\mathrm{Mn}$ & $117 \pm 35$ \\
$\mathrm{Fe}$ & $67.8 \pm 12.4$ \\
$\mathrm{Ni}$ & $16.6 \pm 2.7$ \\
$\mathrm{Cu}$ & $46.8 \pm 21.5$ \\
$\mathrm{Ga}$ & $34.9 \pm 12.1$ \\
$\mathrm{As}$ & $46.4 \pm 9.8$ \\
$\mathrm{Rb}$ & $41.7 \pm 14.4$ \\
$\mathrm{Sr}$ & $20.2 \pm 12.7$ \\
$\mathrm{Cd}$ & $7.4 \pm 1.7$ \\
$\mathrm{Sb}$ & $10.9 \pm 1.9$ \\
$\mathrm{Cs}$ & $5.7 \pm 2.1$ \\
$\mathrm{Ba}$ & $27.2 \pm 9.3$ \\
$\mathrm{La}$ & $41.3 \pm 16.2$ \\
$\mathrm{Ce}$ & $58.8 \pm 21.0$ \\
$\mathrm{Pr}$ & $45.8 \pm 38.5$ \\
$\mathrm{Nd}$ & $52.4 \pm 9.6$ \\
$\mathrm{Sm}$ & $26.7 \pm 13.9$ \\
$\mathrm{Eu}$ & $49.0 \pm 32.5$ \\
$\mathrm{Gd}$ & $21.6 \pm 1.6$ \\
$\mathrm{Dy}$ & $47.5 \pm 34.5$ \\
$\mathrm{Ho}$ & $14.4 \pm 11.2$ \\
$\mathrm{Er}$ & $11.5 \pm 2.9 \pm 7.9$ \\
$\mathrm{Yb}$ & \\
$\mathrm{Pb}$ & \\
\hline &
\end{tabular}

not demonstrate a statistically significant $(p<0.05)$ trend of concentration with depth for three sampled ice cores. $\mathrm{Ca}^{2+}$, $\mathrm{SO}_{4}^{2-}$, DIC, $\mathrm{Cl}^{-}$, and $\mathrm{Na}^{+}$also demonstrated nonsystematic variation with depth. In winter, only three (out of $\sim$ ten) sampled lakes yielded the liquid water presence above the sediment. The thickness of the unfrozen layer ranged from 10 to $20 \mathrm{~cm}$, with an ice thickness of 60 to $80 \mathrm{~cm}$.

Using the element concentration measured in the remaining water at the sediment-ice interface and the bottom $10 \mathrm{~cm}$ layer of the ice core, element distribution coefficients between the ice and the remaining fluid can be assessed. Note 

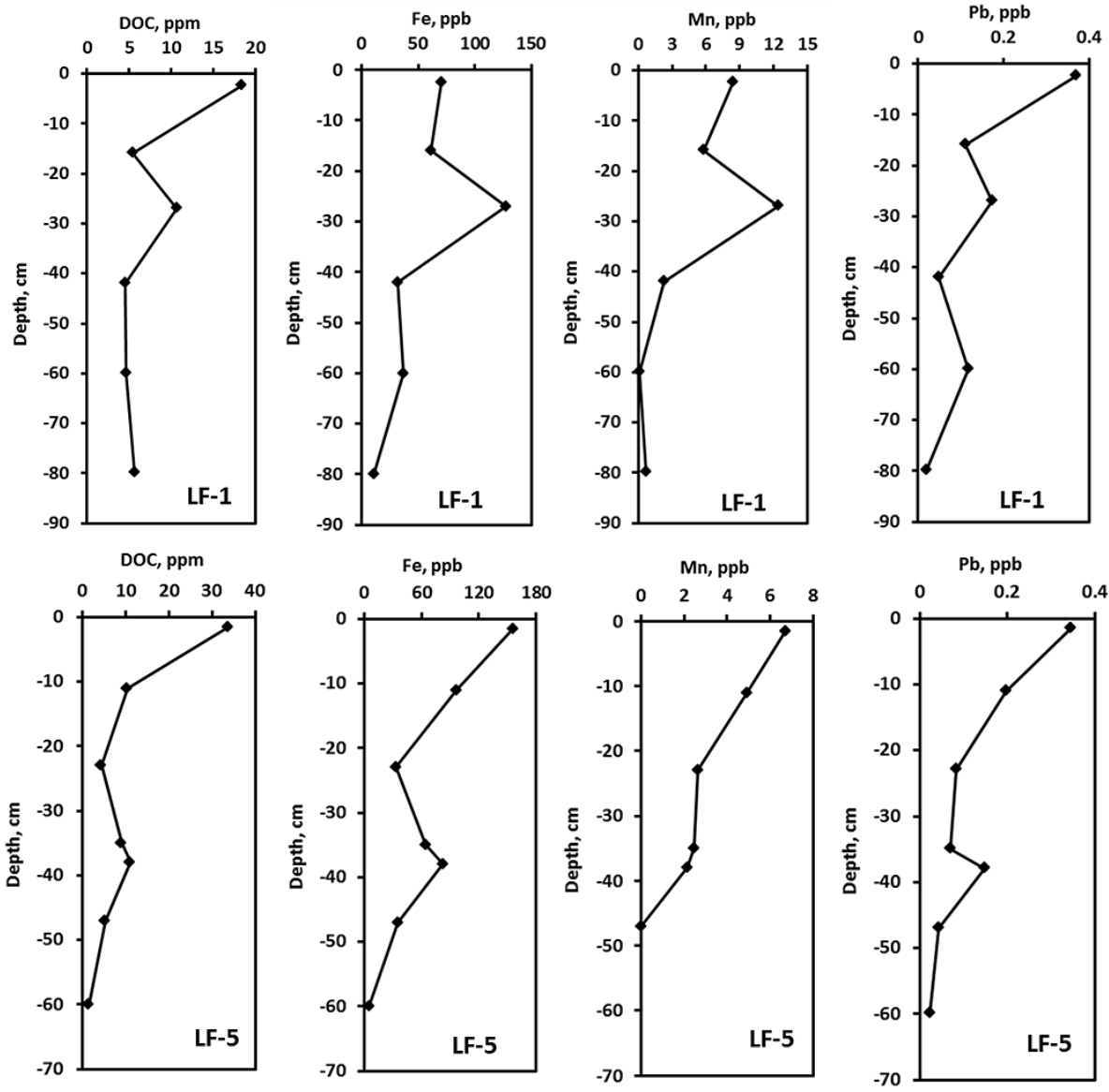

Figure 5. DOC, Fe, Mn and Pb concentrations in the ice cores of thermokarst lakes sampled in February 2014. LF-1 and LF-5 refer to the sampled lakes (Table 1).

that the obtained values can be considered to be preliminary estimations, given the very limited number of samples. The agreement in $K_{\mathrm{d}}$ (water/ice) between three sampled lakes for which both fluid and bottom ice were available is reasonably good for a number of major elements, as can be seen from the average with $2 \mathrm{SD}(n=3)$ listed in Table 2. The lowest $K_{\mathrm{d}}$ (water/ice) is observed for DIC $(1.64 \pm 0.37)$ and $\mathrm{Cl}$ (7.6 \pm 3.0$)$. The DOC distribution varied significantly among the lakes $\left(K_{\mathrm{d}}\right.$ (water/ice) is between 5 and 21$) . \mathrm{Al}, \mathrm{Ti}, \mathrm{Mn}$, $\mathrm{Ce}$ and some REE yielded $K_{\mathrm{d}}$ (water/ice) between 50 and 100 . The majority of other trace elements exhibit the $K_{\mathrm{d}}$ (water/ice) between 10 and 40 without any discernable link to element chemical properties and degree of binding to DOM.

The most significant transformation of the lake water chemical composition presumably occurs during the full freezing of the water column over the winter period. At the end of the winter, during massive snowmelt, products of colloidal coagulation are largely present at the surface of the ice blocks within the lake borders (Fig. S6). The coagulates collected in large $\left(\sim 10^{6} \mathrm{~m}^{2}\right)$ thermokarst lakes in early June are essentially composed of iron oxohydroxide and organic matter with a significant amount of co-precipitated trace el- ements. The aggregates are XRD-amorphous and contain $17.5 \pm 0.5 \%$ of POC.

Based on total chemical analysis of solid co-precipitates, we calculated the distribution coefficients of a trace element (TE) between the Fe-rich coagulates and the lake water, normalized to $\mathrm{Fe}$ (as the major component of the coagulates):

$K_{\mathrm{d}}=[\mathrm{TE}] /[\mathrm{Fe}]_{\text {coagulate }} /[\mathrm{TE}] /[\mathrm{Fe}]_{\text {lake water }}$,

where $[\mathrm{TE}] /[\mathrm{Fe}]_{\text {lake }}$ water represents the ratio of average TE and $\mathrm{Fe}$ concentrations in large lakes at the end of summer, before the beginning of ice formation. The $K_{\mathrm{d}}$ values of major and trace elements range from 0.05 to 0.5 (Fig. 6). Although based on a limited number of samples, the values of the distribution coefficient obtained in the present study are in reasonable agreement with those reported for colloids $(1 \mathrm{kDa}-0.45 \mu \mathrm{m})$ and the LMW $(<1 \mathrm{kDa})$ fraction of another large thermokarst lake located in the discontinuous permafrost zone (Pokrovsky et al., 2011) as well as the rivers and streams of the boreal non-permafrost zone (Vasyukova et al., 2010). For the majority of dissolved elements, the $K_{\mathrm{d}}$ of particles are within a factor of 2 different from the previously reported $K_{\mathrm{d}}$ of colloids. 


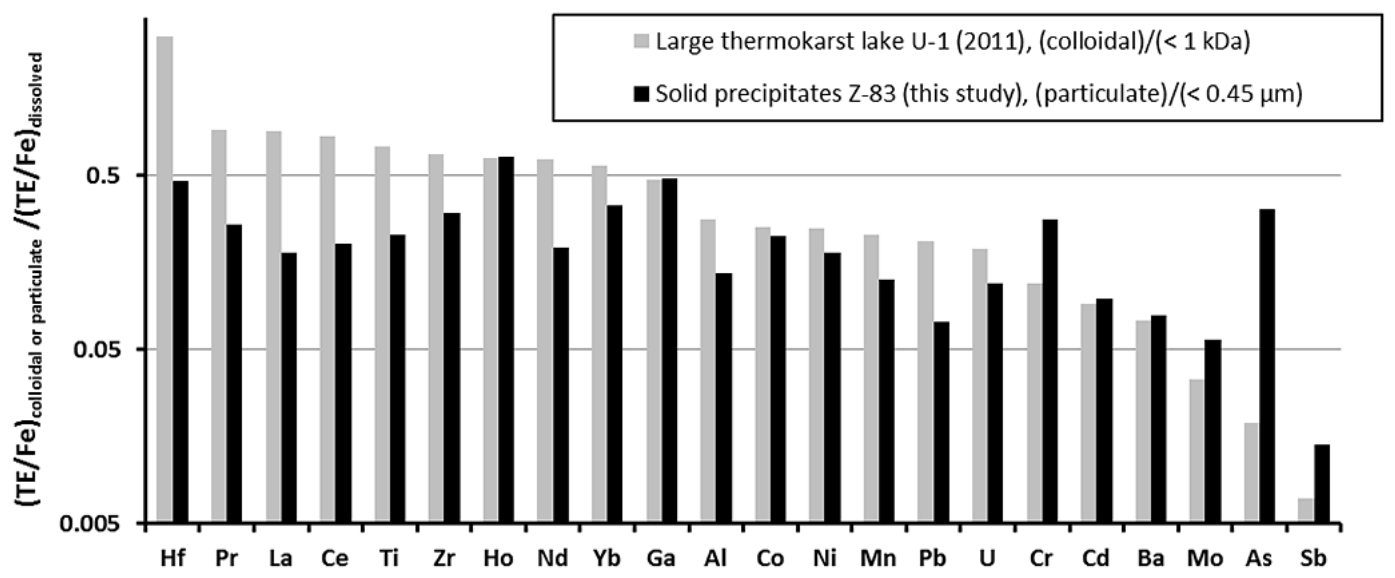

Figure 6. Comparison of the distribution coefficients of a trace element (TE) normalized to Fe between the solid precipitates collected in June from the ice surface of a large lake (Fig. S6) and filtered water (black columns) and those measured between colloids ( $1 \mathrm{kDa}-0.45 \mu \mathrm{m}$ ) and the $\mathrm{LMW}_{<1 \mathrm{kDa}}$ fraction in a large thermokarst lake (Pokrovsky et al., 2011) of the discontinuous permafrost zone (grey columns).

\subsection{Seasonal trend in element concentration in the thermokarst lake water: progressive increase from June to February}

The first statistical test aimed to assess the difference in element concentration between different seasons for the full range of the lake size. It was found, using the H-criterion of the Kruskal-Wallis and Mann-Whitney U tests, which allowed one to estimate the difference between two independent sets of data based on one given parameter, that all elements are different between three main seasons at the significance level of $p<0.05$. This allowed one to calculate the average element concentration with $\pm 2 \sigma$ standard deviation or all studied lake sizes from 100 to $>500000 \mathrm{~m}^{2}$ for spring, summer and autumn, as listed in Table 3. Note that the winter data are of low representativity, given that only three unfrozen lakes could be used for this calculation. The median was similar to the average within the $2 \sigma$ standard deviation of the average.

The majority of dissolved elements exhibited a statistically significant increase in their average concentration from spring to autumn (20 to $50 \%$ ). These are DOC, $\mathrm{Mg}, \mathrm{K}, \mathrm{Ca}$, $\mathrm{Al}, \mathrm{Ti}, \mathrm{V}, \mathrm{Cr}, \mathrm{Mn}, \mathrm{Fe}, \mathrm{Ni}, \mathrm{Co}, \mathrm{Cu}, \mathrm{Ga}, \mathrm{Rb}, \mathrm{Sr}, \mathrm{As}, \mathrm{Cd}, \mathrm{Sb}$, $\mathrm{Mo}, \mathrm{Cs}, \mathrm{Ba}$, all REEs, $\mathrm{Pb}$ and $\mathrm{U}$. Examples of the average element concentration evolution grouped by several families of elements with similar chemical properties and affinity with DOC and Fe colloids (i.e., Pokrovsky et al., 2013) are shown in Fig. 7. The trends of element concentration in the lake water from spring to autumn are quite similar for large $\left(>500000 \mathrm{~m}^{2}\right)$ and medium $\left(100-500000 \mathrm{~m}^{2}\right)$ water bodies. We estimated the minimal impact of lake water freezing, assuming a conservative scenario of element concentration evolution in thermokarst lakes. Based on thorough hydrological observations, we accepted, for $1 \mathrm{~m}^{2}$ of the average lake depth of $75 \pm 25 \mathrm{~cm}$ in summer, to which we added $20 \mathrm{~cm}$ flooding in spring and from which we subtracted $20 \mathrm{~cm}$ of the water layer for ice formation in October. The three sampled lakes exhibited almost full freezing in February, with ca. $10 \mathrm{~cm}$ of bottom water left and $65 \mathrm{~cm}$ of the ice. The concentration factor was calculated as the ratio of the water volume under $1 \mathrm{~m}^{2}$ in a given season to that in spring. It was equal to 1, 1.3, 2.0 and 9.5 for June, August, October and February, respectively.

Conservative behavior of selected major and trace elements is illustrated in Fig. 7 as a dashed line. Most major elements $(\mathrm{Si}, \mathrm{K})$ and a number of trace metals $(\mathrm{Al}, \mathrm{Ti}$, $\mathrm{Cr}, \mathrm{Cu}$ ) exhibited close to conservative behavior. In contrast, DOC demonstrated significant depletion during winter, between October and February. $\mathrm{Fe}, \mathrm{Ni}, \mathrm{Cd}$ and $\mathrm{Pb}$ were slightly non-conservative, showing a depletion in winter. The effect of the season can be quantified as the ratio of the average summer and autumn to spring concentration ( $\left.R_{\text {summer/spring }}\right)$. This ratio is highest for $\mathrm{Ba}$ (6.7) and light REEs (7 to 3), followed by $\mathrm{Zn}$ (4.3), $\mathrm{Si}$ (4.3), Al, Fe and trivalent hydrolysates (4.2 to 2.8), tetravalent hydralysates, $\mathrm{Cr}$ and divalent heavy metals such as $\mathrm{Co}, \mathrm{Cu}, \mathrm{Ni}, \mathrm{Cd}$ and $\mathrm{Mn}$ (2.5 to 3.3). A number of elements did not demonstrate a significant increase in the concentration during the baseflow season compared to the spring period, exhibiting $R_{\text {summer/spring }}$ values below 2 (B, $\mathrm{Mg}, \mathrm{Na}, \mathrm{Ca}, \mathrm{Cs}, \mathrm{Pb}, \mathrm{V}, \mathrm{As}, \mathrm{Sb}$, Th and $\mathrm{Zr}$ ). This empirical result helps to distinguish two groups of elements: elements whose concentrations are affected by the seasons by a factor of 2 or higher and elements that do not significantly increase their concentration in summer relative to the spring seasons. For example, the increase in $\mathrm{Si}$ and metal micronutrients $(\mathrm{Zn}$, $\mathrm{Co}, \mathrm{Ni}, \mathrm{Cu}, \mathrm{Cd}, \mathrm{Ba}$ and $\mathrm{Mn}$ ) might indicate some preferential release of these elements during active plant and upper moss litter leaching in summer. High concentrations of $\mathrm{B}, \mathrm{Na}, \mathrm{Mg}$, $\mathrm{Ca}, \mathrm{Cs}$ and $\mathrm{Pb}$ in early spring relative to the end of summer may indicate their input with atmospheric precipitates. 
Table 3. Average concentrations and standard deviation $( \pm 2 \sigma)$ of major and trace elements during different seasons of the year for two size classes of thermokarst lakes, $100-500000$ and $>500000 \mathrm{~m}^{2}$. Considering all elements simultaneously, the difference between the two size classes is statistically significant ( $p=0.007,0.0008$ and 0.00007 for spring, summer and autumn), as follows from the Wilcoxon $t$ test.

\begin{tabular}{|c|c|c|c|c|c|c|c|c|c|}
\hline \multirow[t]{2}{*}{ Element } & \multirow[t]{2}{*}{ Units } & \multicolumn{3}{|c|}{$100-500000 \mathrm{~m}^{2}$} & \multirow[b]{2}{*}{ Winter } & \multicolumn{4}{|c|}{$>500000 \mathrm{~m}^{2}$} \\
\hline & & Spring & Summer & Autumn & & Spring & Summer & Autumn & Winter \\
\hline DOC & $\mathrm{mgL}^{-1}$ & $15.2 \pm 5.1$ & $25.6 \pm 13.3$ & $28 \pm 10.9$ & N.D. & $13.2 \pm 6.6$ & $12.9 \pm 2.8$ & $16.8 \pm 6.2$ & $27.4 \pm 6.03$ \\
\hline DIC & $\mathrm{mgL}^{-1}$ & $0.38 \pm 0.07$ & $0.42 \pm 0.2$ & $0.79 \pm 0.67$ & N.D. & $0.5 \pm 0.18$ & $0.49 \pm 0.17$ & $1.15 \pm 0.93$ & $0.77 \pm 0.21$ \\
\hline $\mathrm{Cl}^{-}$ & $\mathrm{mgL}^{-1}$ & $0.09 \pm 0.06$ & $0.13 \pm 0.11$ & $0.21 \pm 0.16$ & N.D. & $0.18 \pm 0.05$ & $0.21 \pm 0.14$ & $0.28 \pm 0.13$ & $0.44 \pm 0.25$ \\
\hline $\mathrm{SO}_{4}^{2-}$ & $\mathrm{mgL}^{-1}$ & $0.37 \pm 0.2$ & $0.44 \pm 0.41$ & $0.43 \pm 0.38$ & N.D. & $0.69 \pm 0.27$ & $0.33 \pm 0.15$ & $0.75 \pm 0.5$ & $2.33 \pm 0.65$ \\
\hline Specific cond. & $\mu \mathrm{S} \mathrm{cm}^{-1}$ & $17.9 \pm 5.98$ & N.D. & $7 \pm 1$ & N.D. & $9.8 \pm 1.47$ & N.D. & N.D. & $25 \pm 6$ \\
\hline $\mathrm{pH}$ & & $4.2 \pm 0.34$ & $4.72 \pm 0.58$ & $4.17 \pm 0.38$ & N.D. & $4.44 \pm 0.29$ & $5.49 \pm 0.44$ & $5.21 \pm 0.86$ & $4.72 \pm 0.06$ \\
\hline $\mathrm{Be}$ & $\mu \mathrm{gL}^{-1}$ & $0.004 \pm 0.001$ & $0.007 \pm 0.004$ & $0.013 \pm 0.008$ & N.D. & $0.002 \pm 0.001$ & $0.012 \pm 0.003$ & $0.013 \pm 0.005$ & \\
\hline B & $\mu \mathrm{gL}^{-1}$ & $42.4 \pm 41.8$ & $28.7 \pm 26.5$ & $76.6 \pm 66.3$ & N.D. & $8.22 \pm 7.61$ & $30.1 \pm 20.3$ & $223 \pm 169$ & $776 \pm 413$ \\
\hline $\mathrm{Na}$ & $\mu \mathrm{gL}^{-1}$ & $866 \pm 854$ & $1220 \pm 1197$ & $910 \pm 608$ & N.D. & $997 \pm 782$ & $896 \pm 351$ & $1396 \pm 925$ & $6519 \pm 3818$ \\
\hline $\mathrm{Mg}$ & $\mu \mathrm{gL}^{-1}$ & $99.5 \pm 35$ & $229 \pm 186$ & $150 \pm 76.6$ & N.D. & $62.2 \pm 38.4$ & $125 \pm 12.7$ & $199 \pm 48.3$ & $316 \pm 137$ \\
\hline $\mathrm{Al}$ & $\mu \mathrm{gL}^{-1}$ & $34.7 \pm 18.3$ & $101 \pm 69.4$ & $181 \pm 114$ & N.D. & $41.7 \pm 15.4$ & $137 \pm 77.7$ & $238 \pm 110$ & $484 \pm 169$ \\
\hline $\mathrm{K}$ & $\mu \mathrm{gL}^{-1}$ & $124 \pm 123$ & $207 \pm 203$ & $302 \pm 227$ & N.D. & $256 \pm 144$ & $272 \pm 95.6$ & $447 \pm 253$ & $2251 \pm 1254$ \\
\hline $\mathrm{Ca}$ & $\mu \mathrm{gL}^{-1}$ & $211.4 \pm 92.7$ & $289 \pm 160$ & $309 \pm 152$ & N.D. & $213 \pm 167$ & $470 \pm 367$ & $661 \pm 438$ & $893 \pm 406$ \\
\hline $\mathrm{Ti}$ & $\mu \mathrm{gL}^{-1}$ & $0.512 \pm 0.27$ & $1.16 \pm 0.664$ & $1.76 \pm 1.3$ & N.D. & $0.569 \pm 0.229$ & $4.46 \pm 2.75$ & $4.44 \pm 4.01$ & $3.63 \pm 1.24$ \\
\hline $\mathrm{V}$ & $\mu \mathrm{gL}^{-1}$ & $0.272 \pm 0.088$ & $0.363 \pm 0.252$ & $0.484 \pm 0.361$ & N.D. & $0.415 \pm 0.205$ & $0.848 \pm 0.374$ & $0.882 \pm 0.402$ & $1.33 \pm 0.298$ \\
\hline $\mathrm{Cr}$ & $\mu \mathrm{gL}^{-1}$ & $0.138 \pm 0.075$ & $0.366 \pm 0.166$ & $0.477 \pm 0.274$ & N.D. & $0.157 \pm 0.045$ & $0.457 \pm 0.125$ & $0.651 \pm 0.238$ & $1.14 \pm 0.423$ \\
\hline $\mathrm{Mn}$ & $\mu \mathrm{gL}^{-1}$ & $6.25 \pm 4.39$ & $15.7 \pm 9.92$ & $14.6 \pm 8.95$ & N.D. & $4.14 \pm 3.52$ & $17.9 \pm 4.02$ & $21.1 \pm 8.77$ & $26.3 \pm 11.7$ \\
\hline $\mathrm{Fe}$ & $\mu \mathrm{gL}^{-1}$ & $84.4 \pm 57.3$ & $251 \pm 162$ & $230 \pm 111$ & N.D. & $127 \pm 63$ & $273 \pm 240$ & $336 \pm 146$ & $447 \pm 108$ \\
\hline Co & $\mu g \mathrm{~L}^{-1}$ & $0.037 \pm 0.018$ & $0.103 \pm 0.05$ & $0.141 \pm 0.064$ & N.D. & $0.029 \pm 0.016$ & $0.095 \pm 0.035$ & $0.093 \pm 0.039$ & $0.215 \pm 0.034$ \\
\hline $\mathrm{Ni}$ & $\mu \mathrm{gL}^{-1}$ & $0.108 \pm 0.067$ & $0.316 \pm 0.149$ & $0.299 \pm 0.171$ & N.D. & $0.106 \pm 0.04$ & $0.557 \pm 0.425$ & $0.351 \pm 0.141$ & $0.477 \pm 0.145$ \\
\hline $\mathrm{Cu}$ & $\mu \mathrm{gL}^{-1}$ & $0.252 \pm 0.207$ & $0.47 \pm 0.289$ & $0.789 \pm 0.691$ & N.D. & $0.208 \pm 0.07$ & $0.634 \pm 0.439$ & $1.2 \pm 0.768$ & $3.56 \pm 2.01$ \\
\hline $\mathrm{Zn}$ & $\mu g \mathrm{~L}^{-1}$ & $27.1 \pm 23.3$ & $62.2 \pm 47$ & $114 \pm 97.8$ & N.D. & $27.8 \pm 26.2$ & $108 \pm 97.3$ & $314 \pm 276$ & $794 \pm 423$ \\
\hline $\mathrm{Ga}$ & $\mu \mathrm{gL}^{-1}$ & $0.01 \pm 0.004$ & $0.023 \pm 0.016$ & $0.042 \pm 0.033$ & N.D. & $0.007 \pm 0.004$ & $0.037 \pm 0.023$ & $0.06 \pm 0.031$ & $0.146 \pm 0.069$ \\
\hline As & $\mu \mathrm{gL}^{-1}$ & $0.371 \pm 0.093$ & $0.636 \pm 0.191$ & $0.612 \pm 0.288$ & N.D. & $0.371 \pm 0.069$ & $0.626 \pm 0.057$ & $0.658 \pm 0.182$ & $0.944 \pm 0.3$ \\
\hline $\mathrm{Rb}$ & $\mu \mathrm{gL}^{-1}$ & $0.147 \pm 0.141$ & $0.213 \pm 0.205$ & $0.328 \pm 0.294$ & N.D. & $0.275 \pm 0.069$ & $0.388 \pm 0.166$ & $0.92 \pm 0.536$ & $2.07 \pm 0.963$ \\
\hline $\mathrm{Sr}$ & $\mu \mathrm{gL}^{-1}$ & $2.84 \pm 1.42$ & $5.91 \pm 3.96$ & $8 \pm 5.53$ & N.D. & $3.12 \pm 1.6$ & $8.94 \pm 4.72$ & $13 \pm 6.22$ & $29.5 \pm 12.6$ \\
\hline $\mathrm{Zr}$ & $\mu \mathrm{gL}^{-1}$ & $0.243 \pm 0.2$ & $0.1 \pm 0.068$ & $0.216 \pm 0.165$ & N.D. & $0.488 \pm 0.011$ & $0.309 \pm 0.138$ & $0.612 \pm 0.359$ & $2.06 \pm 1.8$ \\
\hline $\mathrm{Nb}$ & $\mu \mathrm{gL}^{-1}$ & $0.015 \pm 0.011$ & $0.014 \pm 0.012$ & $0.024 \pm 0.023$ & N.D. & $0.013 \pm 0.002$ & $0.024 \pm 0.012$ & $0.02 \pm 0.015$ & 0.024 \\
\hline Mo & $\mu g \mathrm{~L}^{-1}$ & $0.012 \pm 0.007$ & $0.01 \pm 0.009$ & $0.021 \pm 0.015$ & N.D. & $0.023 \pm 0.008$ & $0.021 \pm 0.003$ & $0.021 \pm 0.009$ & $0.033 \pm 0.017$ \\
\hline $\mathrm{Cd}$ & $\mu \mathrm{gL}^{-1}$ & $0.01 \pm 0.007$ & $0.024 \pm 0.015$ & $0.028 \pm 0.013$ & N.D. & 0.0005 & $0.017 \pm 0.01$ & $0.025 \pm 0.019$ & $0.04 \pm 0.008$ \\
\hline $\mathrm{Sb}$ & $\mu \mathrm{gL}^{-1}$ & $0.04 \pm 0.014$ & $0.046 \pm 0.012$ & $0.077 \pm 0.031$ & N.D. & $0.037 \pm 0.01$ & $0.064 \pm 0.015$ & $0.08 \pm 0.027$ & $0.14 \pm 0.044$ \\
\hline Cs & $\mu \mathrm{gL}^{-1}$ & $0.008 \pm 0.007$ & $0.008 \pm 0.007$ & $0.007 \pm 0.006$ & N.D. & $0.003 \pm 0.002$ & $0.013 \pm 0.007$ & $0.023 \pm 0.013$ & $0.027 \pm 0.011$ \\
\hline $\mathrm{Ba}$ & $\mu \mathrm{gL}^{-1}$ & $49.5 \pm 48.9$ & $126.4 \pm 81.2$ & $410 \pm 393$ & N.D. & $63.5 \pm 61.8$ & $139 \pm 77.3$ & $466 \pm 367$ & $1107 \pm 446$ \\
\hline $\mathrm{La}$ & $\mu \mathrm{gL}^{-1}$ & $0.01 \pm 0.007$ & $0.037 \pm 0.031$ & $0.052 \pm 0.041$ & N.D. & $0.003 \pm 0.002$ & $0.072 \pm 0.02$ & $0.071 \pm 0.016$ & $0.221 \pm 0.016$ \\
\hline $\mathrm{Ce}$ & $\mu \mathrm{gL}^{-1}$ & $0.021 \pm 0.014$ & $0.09 \pm 0.083$ & $0.122 \pm 0.114$ & N.D. & $0.001 \pm 0.0009$ & $0.15 \pm 0.052$ & $0.14 \pm 0.02$ & $0.561 \pm 0.04$ \\
\hline $\operatorname{Pr}$ & $\mu \mathrm{gL}^{-1}$ & $0.004 \pm 0.003$ & $0.011 \pm 0.01$ & $0.016 \pm 0.015$ & N.D. & N.D. & $0.018 \pm 0.006$ & $0.017 \pm 0.003$ & $0.065 \pm 0.007$ \\
\hline $\mathrm{Nd}$ & $\mu \mathrm{gL}^{-1}$ & $0.016 \pm 0.011$ & $0.047 \pm 0.045$ & $0.059 \pm 0.055$ & N.D. & $0.028 \pm 0.007$ & $0.078 \pm 0.026$ & $0.074 \pm 0.011$ & $0.215 \pm 0.022$ \\
\hline $\mathrm{Sm}$ & $\mu \mathrm{gL}^{-1}$ & $0.007 \pm 0.005$ & $0.012 \pm 0.011$ & $0.018 \pm 0.017$ & N.D. & $0.011 \pm 0.005$ & $0.019 \pm 0.007$ & $0.018 \pm 0.006$ & $0.063 \pm 0.005$ \\
\hline Eu & $\mu \mathrm{gL}^{-1}$ & $0.013 \pm 0.012$ & $0.019 \pm 0.018$ & $0.036 \pm 0.034$ & N.D. & $0.022 \pm 0.018$ & $0.014 \pm 0.005$ & $0.035 \pm 0.032$ & $0.142 \pm 0.052$ \\
\hline $\mathrm{Gd}$ & $\mu \mathrm{gL}^{-1}$ & $0.009 \pm 0.006$ & $0.013 \pm 0.011$ & $0.019 \pm 0.017$ & N.D. & $0.015 \pm 0.003$ & $0.019 \pm 0.007$ & $0.021 \pm 0.005$ & $0.068 \pm 0.008$ \\
\hline Dy & $\mu \mathrm{g} \mathrm{L}^{-1}$ & $0.011 \pm 0.009$ & $0.012 \pm 0.009$ & $0.016 \pm 0.015$ & N.D. & $0.023 \pm 0.004$ & $0.019 \pm 0.005$ & $0.02 \pm 0.005$ & $0.061 \pm 0.012$ \\
\hline Ho & $\mu \mathrm{g} \mathrm{L}^{-1}$ & $0.002 \pm 0.001$ & $0.003 \pm 0.002$ & $0.005 \pm 0.004$ & N.D. & N.D. & $0.004 \pm 0.002$ & $0.004 \pm 0.0008$ & $0.018 \pm 0.004$ \\
\hline $\mathrm{Er}$ & $\mu \mathrm{gL}^{-1}$ & $0.015 \pm 0.013$ & $0.006 \pm 0.005$ & $0.01 \pm 0.009$ & N.D. & $0.029 \pm 0.002$ & $0.012 \pm 0.003$ & $0.013 \pm 0.002$ & $0.041 \pm 0.008$ \\
\hline $\mathrm{Tm}$ & $\mu \mathrm{gL}^{-1}$ & $0.002 \pm 0.001$ & $0.002 \pm 0.001$ & $0.002 \pm 0.001$ & N.D. & N.D. & $0.002 \pm 0.001$ & $0.002 \pm 0.0009$ & $0.009 \pm 0.001$ \\
\hline $\mathrm{Yb}$ & $\mu \mathrm{gL}^{-1}$ & $0.011 \pm 0.009$ & $0.006 \pm 0.005$ & $0.007 \pm 0.005$ & N.D. & $0.021 \pm 0.003$ & $0.01 \pm 0.003$ & $0.013 \pm 0.004$ & $0.04 \pm 0.007$ \\
\hline $\mathrm{Lu}$ & $\mu \mathrm{gL}^{-1}$ & $0.002 \pm 0.001$ & $0.002 \pm 0.001$ & $0.002 \pm 0.001$ & N.D. & N.D. & $0.002 \pm 0.001$ & $0.002 \pm 0.0006$ & $0.01 \pm 0.005$ \\
\hline $\mathrm{Hf}$ & $\mu \mathrm{gL}^{-1}$ & $0.0065 \pm 0.0015$ & $0.007 \pm 0.006$ & $0.01 \pm 0.008$ & N.D. & $0.0034 \pm 0.0015$ & $0.012 \pm 0.003$ & $0.012 \pm 0.007$ & $0.034 \pm 0.026$ \\
\hline W & $\mu \mathrm{gL}^{-1}$ & $0.016 \pm 0.009$ & $0.083 \pm 0.081$ & $0.115 \pm 0.112$ & N.D. & $0.018 \pm 0.004$ & $0.059 \pm 0.046$ & $0.068 \pm 0.054$ & $0.026 \pm 0.019$ \\
\hline $\mathrm{Pb}$ & $\mu \mathrm{gL}^{-1}$ & $0.199 \pm 0.165$ & $0.266 \pm 0.181$ & $0.487 \pm 0.394$ & N.D. & $0.094 \pm 0.057$ & $0.184 \pm 0.067$ & $0.256 \pm 0.094$ & $0.985 \pm 0.124$ \\
\hline Th & $\mu \mathrm{gL}^{-1}$ & $0.015 \pm 0.048$ & $0.011 \pm 0.009$ & $0.015 \pm 0.01$ & N.D. & $0.011 \pm 0.007$ & $0.023 \pm 0.007$ & $0.018 \pm 0.009$ & $0.026 \pm 0.006$ \\
\hline $\mathrm{U}$ & $\mu \mathrm{gL}^{-1}$ & $0.003 \pm 0.002$ & $0.006 \pm 0.005$ & $0.009 \pm 0.008$ & N.D. & N.D. & $0.01 \pm 0.005$ & $0.008 \pm 0.004$ & $0.029 \pm 0.01$ \\
\hline
\end{tabular}

Despite significant uncertainty in the average summerperiod element concentration in thermokarst lakes (see Table 3 ), the values obtained in the present study are consistent with the thermokarst lake water chemical composition across the gradient of the permafrost zone, from discontinuous/sporadic to continuous permafrost. The values of DOC and all major and trace element concentrations agree, within the uncertainty of the average, with the values of element concentration interpolated from the latitude-lake water concentration dependence (Manasypov et al., 2014) for the latitude of the study site. It follows that the relatively small area investigated in this work can be a good surrogate for a much 

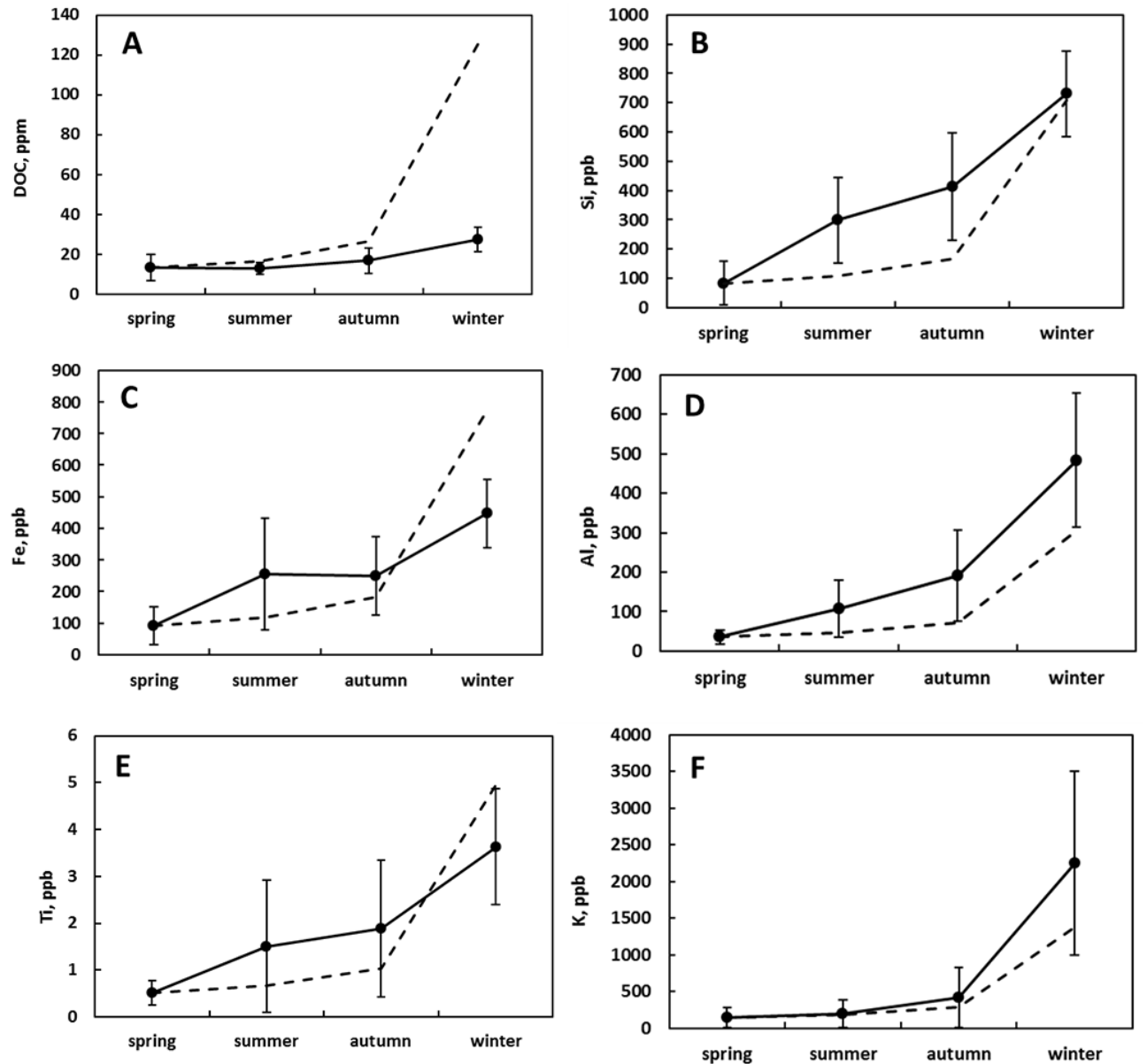

Figure 7. Size-averaged concentrations of DOC (a), $\mathrm{Si}$ (b), $\mathrm{Fe}$ (c), $\mathrm{Al}$ (d), $\mathrm{Ti}$ (e), $\mathrm{K}$ (f), $\mathrm{Zn}$ (g), $\mathrm{Cr}$ (h), $\mathrm{Ni}(\mathbf{i}), \mathrm{Cu}(\mathbf{j}), \mathrm{Cd}(\mathbf{k})$ and $\mathrm{Pb}(\mathbf{l})$ during different seasons. The points are the average and the error bars are the standard deviation. Only the medium and large lakes $\left(>100 \mathrm{~m}^{2}\right.$ surface area) were used for this estimation. The dotted line represents conservative behavior for a hypothetical lake of $75 \mathrm{~cm}$ depth in summer, $20 \mathrm{~cm}$ flooding in spring, surface $20 \mathrm{~cm}$ ice formation in October, and almost full freezing $(10 \mathrm{~cm}$ bottom water left) in February.

larger region of western Siberia (described in Manasypov et al., 2014) in terms of seasonal evolution of thermokarst lake chemical composition.

\subsection{Water residence time effect on lake water chemical composition}

The effect of lake water residence time (WRT) on the summer period and the average spring-autumn chemical composition of thermokarst lakes exhibits two clusters of the data points (Fig. 8). Statistical analysis of observed dependencies confirmed a significant link between the water residence time and both summer and season-average DOC concentrations, with the Spearman correlation coefficient $\left(R_{\mathrm{S}}\right)$ equal to $-0.65(p<0.05)$. The most important result is that, at WRT $<8$ months, an almost five-fold increase in DOC concentration occurs. A similar impact is observed for $\mathrm{Fe}$ with $R_{\mathrm{S}}=-0.55(p<0.05)$. This result can be understood given that the $\mathrm{Fe}$ is likely to be present in the form of or- ganic colloids. The alkaline and alkaline-earth major cations and other metals, however, did not demonstrate any statistically significant $(p>0.05)$ link to the WRT. The estimation of WRT for the smallest $\left(<10-100 \mathrm{~m}^{2}\right)$ water bodies was impossible due to the ephemeral nature of these small thaw ponds. However, considering their typical existence between the start of the snowmelt (May) and summer drought (JulyAugust), the water resides in these water bodies between 0.1 and 0.3 years. The highest concentration of DOC observed in spring in $<10 \mathrm{~m}^{2}$ depressions (Fig. 2) is therefore consistent with the trend shown for large lakes in Fig. 8.

\subsection{PCA analysis of possible TE sources in thermokarst lakes}

The data consisted of $\sim 130$ lake water samples grouped into three distinct seasons (spring, summer and autumn). Statistical analysis considered each chemical element as a variable (35 in total) for all lakes. Considering all seasons together, 

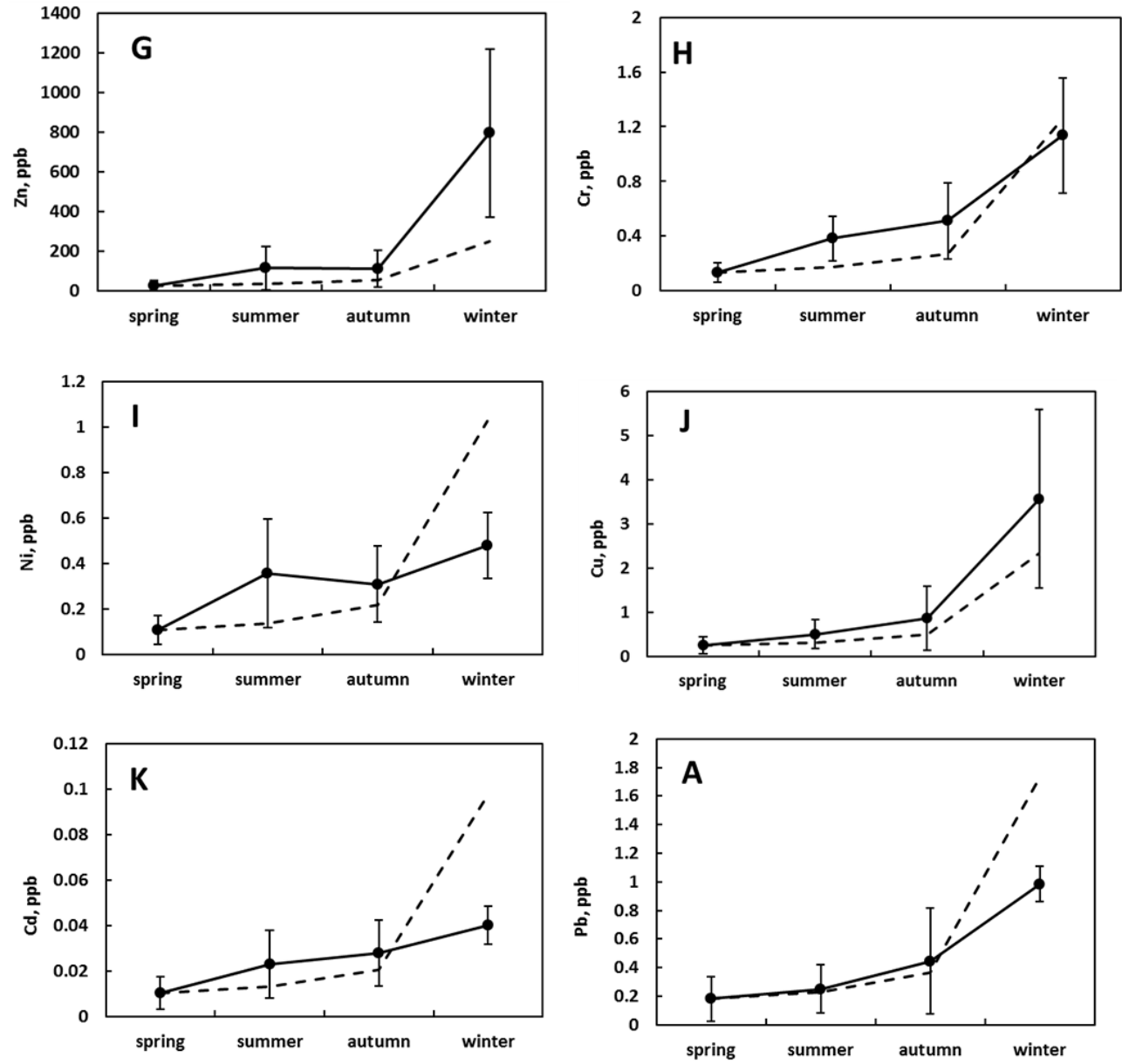

Figure 7. Continued.

the first factor was responsible for $16 \%$ variation and included B, Na, Si, K, Ca, Ti, V, Cr, Ni, Zn, Rb, Mo, Sb, Cs, Ba, $\mathrm{La}, \mathrm{Ce}$ and $\mathrm{U}$, whereas the second factor $(6.3 \%)$ included $\mathrm{Al}$, $\mathrm{Fe}, \mathrm{Co}$, As and Cd (Fig. S7). Separation of F1 and F2 factors in June and August was uncertain since they provided only 9 and $6.7 \%$ (June) and 11.8 and $5.8 \%$ (August) variations. In contrast, October's data could be explained by an $18.8 \%$ variation of $\mathrm{F} 1$ (B, Na, Si, K, Ca, Ti, V, Cr, Ni, Zn, Rb, Sr, Zr, $\mathrm{Mo}, \mathrm{Sb}, \mathrm{Cs}, \mathrm{Ba}, \mathrm{La}, \mathrm{Ce}$ and $\mathrm{U}$ ) and $4.4 \% \mathrm{~F} 2(\mathrm{SO} 4, \mathrm{Cu}, \mathrm{Co}$, $\mathrm{Fe}$ and $\mathrm{As})$. The list of elements and corresponding factors for each season are given in Table S5.

This PCA treatment demonstrated rather high variability of lake chemical composition, mostly pronounced during June and August. In June, multiple factors are responsible for element enrichment in the lake water, namely the lateral input from thaw snow and lake ice, dissolution of colloid coagulation products, and leaching of plant litter. The F1 factor in June is very poorly pronounced. Nevertheless, it may mark the colloidal transport of TE (organic complexes), whereas the second factor may correspond to the degree of snow input (typical atmospheric aerosol-originated elements). In August, internal (autochthonous) processes and subsurface feeding are likely to strongly modify lake water chemical composition both for major (pH and DIC of the F2 factor) and TE. In addition, atmospheric precipitation in the form of rain that dilutes lithogenic TE but also delivers marine aerosols and dust (subjected to dissolution) can strongly modify the role of individual correlations. Finally, October represents the period when the first factor is mostly pronounced, as also translated in the PCA results of all seasons together. Presumably, the period of the beginning of ice formation corresponds to the maximal stability of the F1 $\times$ F2 structure; during this time, the influence of both allochthonous (lateral and subsurface TE influx from peat, mineral soil horizons and ground vegetation) and autochthonous (bio- and photo-destruction of organic colloids, primary productivity) processes is minimal.

\subsection{Element speciation in thermokarst lake waters}

We used geochemical program Visual MINTEQ (Gustafsson, 1999), version 3.1 (October 2014) for Windows (see Unsworth et al., 2006, for a vMINTEQ application exam- 

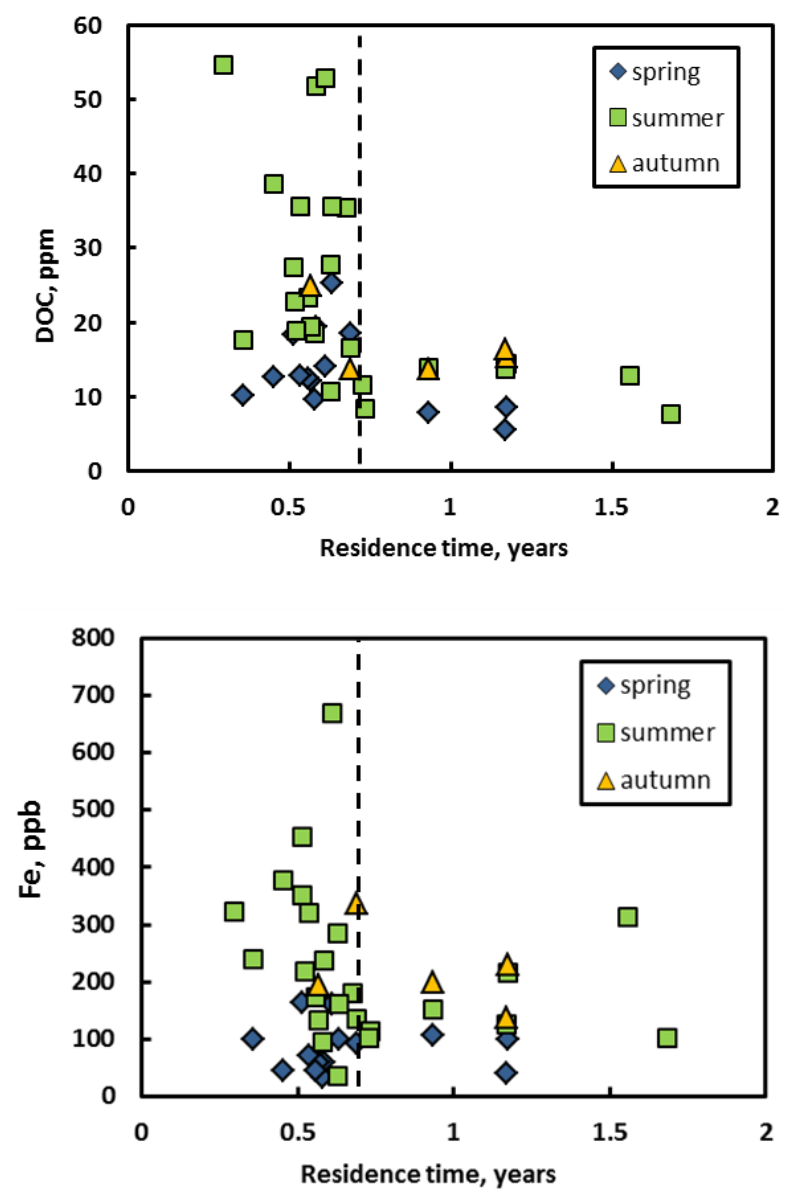

Figure 8. DOC (a) and Fe (b) concentrations during different seasons plotted as a function of water residence time in the water body. Vertical dashed line marks the beginning of concentrationresidence time independence.

ple), in conjunction with a database, the NICA-Donnan humic ion binding model (Benedetti et al., 1995; Milne et al., 2003) and the Stockholm Humic Model (SHM). Speciation calculations were performed for $\mathrm{Ba}, \mathrm{Ca}, \mathrm{Cd}, \mathrm{Co}, \mathrm{Cu}, \mathrm{K}, \mathrm{Mg}$, $\mathrm{Mn}, \mathrm{Na}, \mathrm{Ni}, \mathrm{Pb}, \mathrm{Sr}, \mathrm{Zn}, \mathrm{Al}, \mathrm{Fe}^{\mathrm{III}}, \mathrm{Th}^{\mathrm{IV}}$ and $\mathrm{U}^{\mathrm{VI}} \mathrm{O}_{2}$ for average lake water composition in spring, summer, autumn and winter as well as the average August composition of large $\left(>500000 \mathrm{~m}^{2}\right)$ and small $\left(100-500000 \mathrm{~m}^{2}\right)$ lakes (Table 3). In addition to the NICA-Donna approach, the Stockholm Humic Model (SHM) of visual MINTEQ was used to calculate metal speciation in the lake water.

Results of the calculation of metal degree of complexation with DOM are listed in Table S6 and illustrated in Figs. S8 and S9. According to the NICA-Donnan model, the majority of divalent major and trace elements are bound to organic, Donnan-like complexes. Only Na and K exhibit a decrease of 80 to $10 \%$ complexed fraction from spring to winter. Extremely high complexation of metals with DOM (up to 80 to $90 \%$ ) within the NICA-Donnan concept is supported by dialysis experiments conducted in various thaw lakes of the west- ern Siberian subarctic (Pokrovsky et al., 2013; Shirokova et al., 2013). In contrast to the NICA-Donnan, the Stockholm Humic Model (SHM) predicts moderate and quite variable association of divalent metals with DOM, with the lowest values for $\mathrm{Ba}$ and $\mathrm{Mn}$ (40\% in spring and $20 \%$ in winter) and the highest values for $\mathrm{Cu}$ and $\mathrm{Pb}(80-90 \%$ for all seasons). It is important to note that the highest proportion of organic complexes is observed in summer, presumably due to the highest $\mathrm{pH}$ recorded during this season, which favors the deprotonation of functional groups of the DOM. The lowest proportion of organic complexes in winter could be due to competition between metals for organic ligand binding sites, given the significant increase in $\mathrm{Me}^{2+}$ compared to DOC during solute concentration by freezing.

The lake size has a pronounced impact on some metal complexation with DOM as illustrated in Fig. S9. Even within the "conservative" SHM model, the TE in small thaw ponds exhibits $100 \%$ complexation with DOM. The degree of complexation is smaller in large lakes with a factor of 2 lower DOC concentration, despite the fact that their $\mathrm{pH}$ is higher than that of small lakes (5.49 and 4.72, respectively). Interestingly, this may indicate higher bioavailability of metal micronutrients in large lakes, in line with the hydrobiological evolution of western Siberia thermokarst lakes, namely the elevated productivity and the presence of macrophytes and phytoplankton blooms in large mature thermokarst lakes (Pokrovsky et al., 2014). Another important conclusion from the speciation modeling is that the DOC concentration has a more pronounced impact on metal speciation (notably the \% of organic complexes) than the $\mathrm{pH}-$ both across the seasons and different lake size groups.

\section{Discussion}

\subsection{Lake water composition control by snow and ice melt in spring}

All trends described in this work on numerous lake analysis are confirmed by the data of five lakes sampled throughout the year. This is illustrated for $\mathrm{pH}, \mathrm{DOC}, \mathrm{Al}$ and $\mathrm{Cu}$ for the same five lakes sampled in spring, summer and autumn. For a large range of lake surface area, the trend spring $<$ summer $<$ autumn is clearly visible and statistically significant $(p<0.05)$.

The lack of a trend in DOC and metal concentration with the lake surface area increase above $1000 \mathrm{~m}^{2}$ (Fig. 2, Table $\mathrm{S} 1, R^{2}=0.17, R_{\mathrm{S}}=-0.33$ ) in June implies that the lakes are essentially influenced by allochthonous (surface runoff from snowmelt) sources of dissolved material with minimal transformation of DOC and metal complexes by intra-lake autochthonous processes. In the opposite case, one would expect a tendency of DOC and chemical element increase with the decrease in the size of the water body, notably below $100 \mathrm{~m}^{2}$, as it is encountered in summer periods in the spo- 
radic and discontinuous and permafrost zone of thermokarst lake development (Shirokova et al., 2013). Given that the upper part of the peat column is still frozen in the beginning of June, the source of the solutes to the lake water is most likely to be ground vegetation, comprising dwarf shrubs, mosses and lichens, as well as the litter fall of the previous year. The input of the vegetation leaching products should be similar for the lakes of different sizes, given the very homogeneous palsa bog dominant landscape at the study site.

The spring flood period is known to be the most important in terms of land coverage by water, on the annual scale ( $\mathrm{Za}$ kharova et al., 2009, 2014). As a result, the average chemical composition of the dominant surface waters in the discontinuous permafrost zone of western Siberia can be approximated by that of the spring period as listed in Table 3. Elevated DOC concentration in thermokarst lakes during the spring period, a factor of 2 to 3 higher than the typical 10$15 \mathrm{mg} \mathrm{L}^{-1}$ of boreal waters (Dillon and Molot, 1997), suggests a high potential for releasing $\mathrm{CO}_{2}$ into the atmosphere, notably in numerous small depressions filled by thaw water.

A systematic $(p<0.05)$ increase in the average slope of dependence $\mathrm{UV}_{280 \mathrm{~nm}}-[\mathrm{DOC}]$ in the course of the season (Fig. 3), from 0.024 in spring to 0.0354 in winter (the latter with only three samples), suggests an increase in the input of aromatic compounds (presumably from peat lixiviation) to the end of the vegetative season relative to the leaching of fresh vegetation products (low aromatic, plant and litter exudates) mostly visible after the snowmelt, when the surrounding peat is still frozen. Correcting the UV absorbance for dissolved $\mathrm{Fe}^{3+}$ (Weichaars et al., 2003) by subtracting a term of $0.08 \times[\mathrm{Fe}, \mathrm{ppm}]$ will change the $\mathrm{UV}_{280 \mathrm{~nm}}$ value by less than $10 \%$, which is beyond the variability of the seasons and lake size. Note also that a recent study of DOC-UV properties at a boreal site demonstrated the absence of the influence of nitrate and iron on UV and visual absorbance of up to $2.2 \mathrm{mg} \mathrm{L}^{-1}$ of Fe(III) (Avagyan et al., 2014). The lack of any trend $(p>0.05)$ in the UV / DOC ratio as a function of the lake size (Fig. 3) strongly suggests the similarity of the DOC sources in the full range of the lake size in each season. As a result, the season rather than the lake size at $S>100 \mathrm{~m}^{2}$ seems to be the most important factor controlling both the average concentration and the chemical nature of DOC and related elements.

Comparison of TE concentrations in summer relative to spring (Sect. 3.3) distinguishes two groups of elements: elements that do not significantly increase their concentration in summer relative to the spring and elements whose concentrations are affected by the seasons by a factor of 2 or higher. For example, the increase in $\mathrm{Si}$ and metal micronutrients $(\mathrm{Zn}, \mathrm{Co}, \mathrm{Ni}, \mathrm{Cu}, \mathrm{Cd}, \mathrm{Ba}$ and $\mathrm{Mn})$ in summer relative to spring might indicate some preferential release of these elements during active plant and upper moss litter leaching in relatively warm waters. In contrast, high concentrations of $\mathrm{B}, \mathrm{Na}, \mathrm{Mg}, \mathrm{Ca}, \mathrm{Cs}$, and $\mathrm{Pb}$ in early spring compared to the
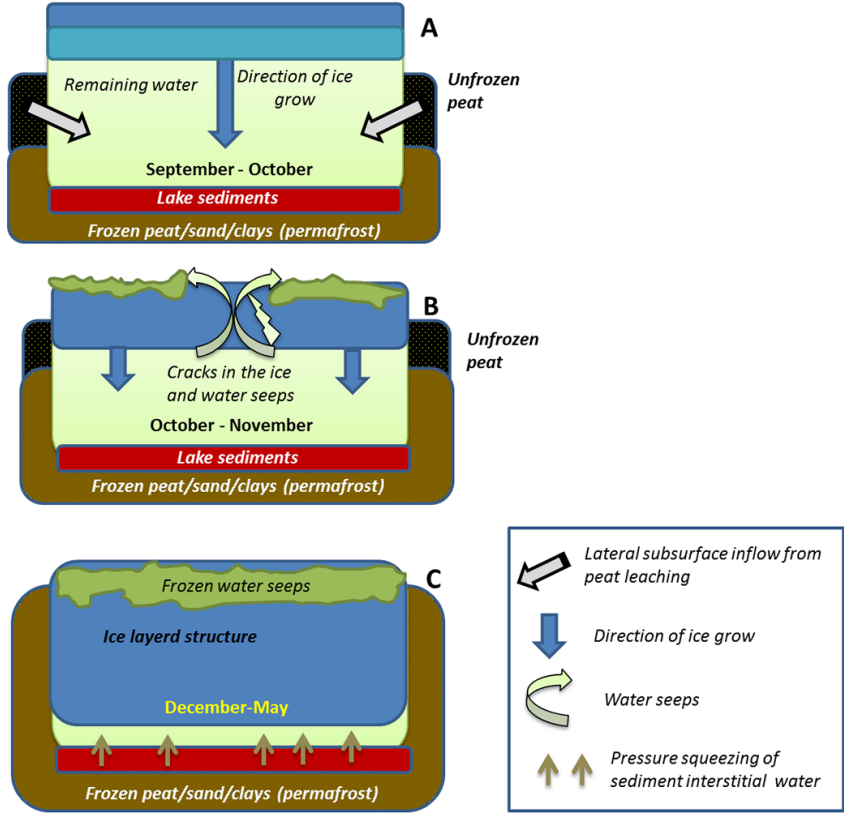

Figure 9. Sequence of ice crystallization events during the glacial period on the shallow ( $<1 \mathrm{~m}$ depth) thermokarst lakes of western Siberia. (a) Start of the ice formation; (b) squeezing water towards the surface via seeps; (c) freezing of water pockets and seeps and multi-layer ice formation.

end of the summer may indicate their input with atmospheric deposition after snowmelt.

\subsection{Concentration mechanism during freezing period; enhanced colloidal coagulation}

The unusual distribution of organic carbon and related trace elements over the ice core profile, with an accumulation in the upper $20-40 \mathrm{~cm}$ of the ice column, stems from a sequence of events during lake freezing, linked to (i) shallow depth and the possibility of the full freezing of the water column and (ii) the lack of any outlet or hydraulic connection to the groundwater of these confined water bodies underlain by the impermeable permafrost layer in the form of the frozen sand/peat. The hypothetical scheme of a crystallization process is illustrated in Fig. 9. The squeezing of remaining water from the bottom towards the surface through the ice cracks starts as early as October. This produces the layered, organic- and Fe-rich secondary (allochthonous) ice that is crystallized at the already frozen lake surface. During winter, the progressive freezing downward from the water column and the decrease in the connectivity between the remaining water and the lake surface bring about the decrease in element concentration in the bottom ice while concentrating solutes in the remaining fluid at the ice-sediment interface. The progressive lake freezing produces layered ice with contrasted content of major and trace elements among different layers, reflecting the full freezing of water pockets formed via 
seeping the bottom water at the lake surface. The DOC and many related elements exhibit a general decrease in concentration downward from the ice core surface. The freezing sequence of the thermokarst lakes contrasts with the freezing of non-permafrost (glacial) lakes, which are generally deeper than $1 \mathrm{~m}$ and have an inlet/outlet and underground connection. To which degree the scheme of ice formation suggested for shallow thermokarst lakes in the discontinuous permafrost zone can be applied to other, sporadic and continuous permafrost regions of western Siberia, remains unknown. However, given the shallow depths and closedbasin settings of most thermokarst lakes, the extrapolation of obtained ice chemistry data and partitioning coefficients to other thermokarst lakes of western Siberia should be possible.

To our knowledge, the information on TE partitioning between the lake water and the ice for other boreal settings is lacking. The similar range of DOC and many major and trace metal distribution coefficients between the ice and the remaining solution encountered in the present study (Table 2) is remarkable and contrasts with the recent results of DOM incorporation during sea ice formation (Muller et al., 2013). The latter authors argued that DOM is incorporated into sea ice relatively more than inorganic solutes. In the case of low total dissolved solid (TDS), DOM-rich thermokarst lakes of the present study, the majority of solutes may follow the DOC being present as organic colloids $(1 \mathrm{kDa}-0.45 \mu \mathrm{m})$, as follows from vMINTEQ speciation calculation (Sect. 3.6) and as also demonstrated by dialysis experiments (Pokrovsky et al., 2011, 2013).

Various physico-chemical processes may be involved in the transformation of solutes and DOM and metal-rich water pockets incorporated into the ice, notably within its most surface layers. Among them, photoreductive dissolution of iron oxy(hydr)oxide trapped in the ice (i.e., Kim et al., 2010) can occur both in winter and spring, during massive ice melting. The enrichment of both $\mathrm{Fe}$ and $\mathrm{Mn}$ in the first $20 \mathrm{~cm}$ of the ice column relative to the deeper ice layers (Fig. 5) can certainly promote enhanced reductive dissolution of both $\mathrm{Mn}$ (Kim et al., 2012) and Fe (Kim et al., 2010) under ice thaw during polar day in early June. However, the Fe(II) fraction was estimated to be below $10 \%$ in June's lake sampling, as the $\mathrm{LMW}_{<1 \mathrm{kDa}}$ fraction containing essentially uncomplexed $\mathrm{Fe}^{2+}$ (aq) was $\leq 5 \%$ of the total dissolved $\mathrm{Fe}$ (see the method of $\mathrm{Fe}(\mathrm{II})$ analysis in the lake water by the in situ dialysis technique in Pokrovsky et al., 2012). Therefore, oxygenated spring waters and shallow depths of thermokarst lakes provide favorable conditions of $\mathrm{Fe}(\mathrm{III})$ colloid formation in these organic-rich water bodies. Highly non-conservative behavior of DOC during the winter time demonstrating significant depletion in February (Fig. 7a) may suggest some heterotrophic respiration of DOM under the ice. Alternatively, the DOC could be transformed into POC and precipitated to the lake bottom or be trapped as particles in the growing ice.
Note that the $\mathrm{Zn}$ concentration in winter becomes very high, up to $1 \mathrm{mg} \mathrm{L}^{-1}$ (Fig. $7 \mathrm{~g}$ ). The main reason for such an increase in $\mathrm{Zn}$ concentration could be its high mobility in acidic, organic-rich aquatic systems. The additional mobilization of $\mathrm{Zn}$ from moss cover at the lake border during its freezing can be linked to the release of $\mathrm{Zn}$ from the cell cytoplasm during freeze-induced submerged vegetation cell damage. However, the concentration factor for $\mathrm{Zn}$ is not dramatically different from that of the other elements: it is similar to that of $\mathrm{Cu}, \mathrm{Zr}, \mathrm{B}, \mathrm{Na}, \mathrm{K}$, REEs and $\mathrm{U}$, and is even lower than that of $\mathrm{Pb}$. As such, we consider high element concentration during winter to be a consequence of solute concentration during freezing rather than a specific mechanism of metal mobilization from ground and bottom vegetation subjected to freezing.

During the massive ice melting, a significant number of coagulated organo-ferric particles remain on the ice surface (Fig. S6) and eventually precipitate to the lake bottom. Although under anaerobic conditions in the thermokarst lake sediments, $\mathrm{Fe}(\mathrm{III})$ may be reduced and return to the water column (Audry et al., 2011), the majority of Fe oxyhydroxide is likely to remain in particulate form, thus preventing Fe from moving to the hydrological network during spring floods. We hypothesize that one of the most powerful mechanisms of organic and organo-mineral colloid coagulation in thermokarst water bodies is annual freezing of the whole water column leading to significant concentrations of $\mathrm{Fe}, \mathrm{C}_{\text {org }}$ and related divalent metals and trivalent and tetravalent hydrolysates in the particulate phase. In the northern part of the discontunuous permafrost zone, the lake sediments are indeed enriched in $\mathrm{Fe}$ and trivalent and tetravalent hydrolysates (Audry et al., 2011). It is remarkable that Fe-normalized distribution coefficients of TE between the organo-ferric coagulates and filtered $(<0.45 \mu \mathrm{m})$ lake water (Fig. 6) are of the same order of magnitude or within a factor of 2 different from the distribution coefficients of TE between Fe-rich colloids $(1 \mathrm{kDa}-0.45 \mu \mathrm{m})$ and the $\mathrm{LMW}_{<1 \mathrm{kDa}}$ fraction assessed in previous studies in thermokarst lakes (Pokrovsky et al., 2013) and boreal surface streams (Vasyukova et al., 2010). This similarity strongly suggests that the elementary mechanisms of TE incorporation into organic matter-stabilized Fe oxyhydroxides include mainly co-precipitation and that it is generally similar for colloids and particles.

\subsection{Allochthonous versus autochthonous processes forming lake water chemical composition}

Allochthonous processes forming lake water chemical composition include the input of fresh vegetation products and the leaching of the upper peat layer. At the beginning of the active season, in June, there is a lateral input of melting snow, reflecting the interaction of water with ground vegetation such as mosses and lichens as well as with the litter fall of the dwarf shrubs from the previous year. During the summer (baseflow) season, there is a peat leaching at the lake 
border via mainly wave abrasion and elements and DOC release from moss and lichen coverage via lateral flow fed by rains.

The DOM entering the lake ecosystem with the snowmelt and surface inflow during summer rain is subjected to two processes of autochthonous transformation during the open water period: photo- and bio-degradation, mostly pronounced in June-September (i.e., Larouche et al., 2015). During summer, the productivity of phytoplankton including possible exometabolite release represents less than $10 \%$ of heterotrophic bacterioplankton respiration in western Siberia thermokarst lakes of the discontinuous/sporadic permafrost zone (Shirokova et al., 2013). The heterotrophic bacterioplankton activity brings about the conversion of colloidal DOM and low molecular weight (LMW) organic ligands to particulate organic matter (POM) in the form of coagulates or the bacterioplankton biomass; in both forms, the POM is likely to precipitate to the lake bottom in the course of the active season. During the glacial period, the processes leading to sedimentation of POC to the lake bottom are cryoconcentration and colloid coagulation (see Sect. 4.2 and Fig. S6). The physico-chemical coagulation of DOC may become especially important during progressive lake freezing in winter. Highly non-conservative behavior of DOC (Fig. 7a) relative to the other major components $(\mathrm{Si}, \mathrm{K}, \mathrm{Na}$ ) strongly suggests the preferential removal of DOC from the remaining water under the ice cover. The other elements such as the metals $\mathrm{Fe}, \mathrm{Ni}, \mathrm{Cd}$ and $\mathrm{Pb}$ (Fig. 7c, i, $\mathrm{k}$ and l, respectively) follow the non-conservative behavior of DOM, suggesting their massive removal from the water column in the form of organic coagulates. In contrast, $\mathrm{Al}, \mathrm{Ti}, \mathrm{Zn}, \mathrm{Cr}$ and $\mathrm{Cu}$ (Fig. 7d, e, g, h and $\mathrm{j}$, respectively) remain conservatively in the bottom water or even accumulated in the water. It is possible that they are less dependent on large-size DOM colloids mostly subjected to coagulation during cryoconcentration. Indeed, these metals could be bound to $\mathrm{LMW}_{<1 \mathrm{kDa}}$ organic complexes and thus remain in unfrozen water in the lake bottom layer. Additional input of $\mathrm{Al}$ and $\mathrm{Ti}$ from mineral clay sediments of the lake (i.e., Audry et al., 2011) cannot be excluded.

The behavior of DIC is almost conservative during lake freezing, without any excess of DIC over the theoretical value in February. As a result, there is no significant accumulation of inorganic carbon in the form of $\mathrm{CO}_{2}$ or $\mathrm{HCO}_{3}^{-}$ under the ice cover. This result strongly suggests the dominance of physico-chemical coagulation rather than microbial respiration in DOC removal from the water column in winter. The latter process dominates the open water period, when heterotrophic aerobic bacterioplankton respiration of allochthonous DOM produces gaseous $\mathrm{CO}_{2}$ that is released into the atmosphere in western Siberia thermokarst lakes that are strongly supersaturated with respect to the atmosphere (Shirokova et al., 2009, 2013), similar to the other boreal lakes (Jansson et al., 2008; Rautio et al., 2011). The response of this microbial process to the DOC input in the lake may be fast, on the order of days, given that (i) we observed elevated
( $>20 \mathrm{mg} \mathrm{L}^{-1}$ ) DOC concentrations in the smallest $\left(<2 \mathrm{~m}^{2}\right)$ ground depressions formed within hours after snowmelt, and (ii) that the leaching of DOM from plant litter is very fast, on the order of hours (Berg, 2000; Fraysse et al., 2010).

A plot of DOC concentration versus water residence time in medium and large lakes $\left(300-1200000 \mathrm{~m}^{2}\right)$ revealed two clusters of the data points, with maximal DOC concentration observed in lakes and ponds of short-term water circulation and a stable and rather low DOC concentration $\left(10 \pm 5 \mathrm{mg} \mathrm{L}^{-1}\right)$ in lakes of slow water turnover (Fig. 8a). Since the allochthonous input increases DOC in the water body and autochthonous microbial respiration and physicochemical coagulation remove DOC from the water column, the former process is certainly dominant for short-lived water bodies. The hydrological balance of the smallest water depressions $\left(<200 \mathrm{~m}^{2}\right)$ could not be quantitatively assessed, but it can be suggested that the lowest water residence time in these, partially ephemeral, water bodies is consistent with the highest DOC measured in this study. In the lakes of slow water turnover, the input and removal of DOC are presumably balanced. Note, however, the similarity of the intensity of autochthonous processes in larger lakes (i.e., $\geq 100000 \mathrm{~m}^{2}$ ), regardless of their size and the water residence time.

\subsection{Seasonal evolution of stock of carbon and TE in thermokarst lakes}

The average of the six smallest $\left(<1 \mathrm{~m}^{2}\right)$ depressions sampled in spring shows a factor of $2.3(p<0.05)$ higher concentration of dissolved organic carbon $\left(30.8 \pm 7.3 \mathrm{mg} \mathrm{L}^{-1}\right)$ compared to the larger water bodies $\left(13.2 \pm 6.6 \mathrm{mg} \mathrm{L}^{-1}\right)$ during this period. This strongly suggests the importance of shortterm plant debris (litter) and submerged ground vegetation leaching occurring right after the snowmelt. On the western Siberia lowland, the water stock is highest during the spring period, notably in terms of water coverage of the land depressions (60 to $70 \%$ of the overall watershed area; Zakharova et al., 2014). According to satellite observations in western Siberia, the area subjected to the spring flood period is 55$65 \%$ higher than that of the summer period (Zakharova et al., 2014). Taking into account these observations, and the DOC concentration in thermokarst water bodies, we estimate that the overall increase in the soluble stock of DOC and related metals in surface waters in June relative to August may be as high as $200-500 \%$. This value stems from (i) a factor of 2-3 increase in the wetland flooding in June compared to the summer baseflow season multiplied by (ii) a factor of $1.5-2$ higher DOC and metal concentrations in small $\left(<1-10 \mathrm{~m}^{2}\right)$ water bodies compared to the larger lakes. This dissolved fraction may be easily mobilized from the watershed to the river and further transported to the ocean.

In shallow thermokarst lakes, progressive ice melt from the surface towards the bottom slowly liberates inorganic carbon trapped or dissolved in the ice. The $K_{\mathrm{d}}$ (water/ice) for DIC (1.2-2.2) is much lower compared to other ele- 
ments including DOC. As such, the ice is not particularly enriched in DIC relative to the bottom water and both winter and spring period DIC and $\mathrm{CO}_{2}$ concentrations are not significantly higher than those in summer. At present, we do not know of any seasonal measurements of $\mathrm{CO}_{2}$ and $\mathrm{CH}_{4}$ in thermokarst water bodies of western Siberia. Our unpublished data (Fig. S11) do not demonstrate any significant enrichment in $\mathrm{CO}_{2}$ or $\mathrm{CH}_{4}$ during spring flood. Only in very small depressions $\left(<10 \mathrm{~m}^{2}\right)$ does the $\mathrm{CO}_{2}$ level increase. Given that the concentration of methane is 1 to 2 orders of magnitude lower than that of $\mathrm{CO}_{2}$ and that $\left[\mathrm{CH}_{4}\right]$ is independent of the depression size, the role of methane oxidation in $\mathrm{CO}_{2}$ enrichment is negligible. Overall, we do not expect significant buildup of $\mathrm{CO}_{2}$ under ice and $\mathrm{CO}_{2}$ release from the lake water into the atmosphere during spring melt, contrasting with well-known phenomena on deep boreal lakes (Karlsson et al., 2013). The reasons for this contrast could be low volume of the thermokarst lake water and a relatively short period suitable for this accumulation in western Siberia, since already in February, there is a lack of liquid water under the ice, yielding a very low fraction (between 10 and $20 \%$ ) of this unfrozen water stock. Altogether these arguments suggest that the only mechanism capable of enriching the lake water in $\mathrm{CO}_{2}$ during spring melt is heterotrophic respiration of "fresh" allochthonous DOM, as confirmed by the elevated DOC concentration during this period, notably in small water bodies.

\section{Conclusions}

A hydrochemical study of shallow thermokarst lakes from a discontinuous permafrost zone of western Siberia revealed conceptually new features of element concentration evolution over different seasons within a large scale of the lake size. Statistical treatment demonstrated that there is no significant difference in element concentration as a function of the lake size within the range of $2 \times 10^{2}-2 \times 10^{6} \mathrm{~m}^{2}$ in June, August and October. However, in spring, there was a clear increase in DOC and related metal concentrations with the decrease in the size of small water bodies $\left(<200 \mathrm{~m}^{2}\right)$. Such small ponds disappear in summer due to evaporation and quickly freeze solid at the very beginning of the glacial season. Most of the dissolved elements and organic carbon decreased their concentration following the order June $<$ August $<$ October, regardless of the lake size range, from $2 \times 10^{2}$ to $2 \times 10^{6} \mathrm{~m}^{2}$. Therefore, although there are statistically significant differences in organic carbon and major and trace element concentrations between different seasons, the lake size has a negligible influence on the lake water chemical composition, except in very small water bodies sampled only in spring. The water residence time (WRT) may be an important parameter controlling lake DOC and Fe concentrations, especially for short-lived water bodies, mostly present during spring. In contrast, the other major and trace elements did not demonstrate any clear link with WRT in the lake.

The ice formation in October created an excessive pressure within the confined water body; the remaining organicand Fe-rich water was seeping onto the ice surface via cracks of the ice cover. This seeping produced the ice of multiple layers with significant enrichment in Fe, DOC and trace elements in the frozen water pockets within the first $0-20 \mathrm{~cm}$ in depth. Massive coagulation of organo-ferric colloids occurred during full freezing of the lake water and produced macroscopic, organic- and Fe-rich amorphous particles capable of precipitating to the lake bottom. The main mechanisms of element differentiation during ice formation are concentration and coagulation of organic and organo-mineral colloids, as shown by the highly non-conservative behavior of DOC and related metals. The partitioning coefficients of TE between the lake water $(<0.45 \mu \mathrm{m})$ and the particulate coagulates reflecting the degree of element differentiation during ice formation and full water column freezing were similar to those measured for Fe-rich colloids $(1 \mathrm{kDa}-0.45 \mu \mathrm{m})$ in other thermokarst and boreal lakes and rivers.

The spring flood period created the highest stock of dissolved allochthonous DOC and related metals, notably in small $\left(<200 \mathrm{~m}^{2}\right)$ water bodies and depressions. The water dilution during this period (e.g., typically $20 \%$ of the water volume increase) can compete with the increase in the land surface coverage for the overall element stock in lakes in June relative to August. We estimate that the overall increase in the soluble stock of DOC and related metals in surface waters and, consequently, the potential for river water feeding by lakes during spring floods, ranged from a factor of 2 to 5. Further assessment of this increase requires highresolution $\left(<0.5-1 \mathrm{~m}^{2}\right)$ remote sensing observations coupled with in situ hydrochemical measurements. Given the significant coverage of the land surface by thaw water in spring and elevated DOC concentrations during this period, the overall impact of snowmelt on $\mathrm{CO}_{2}$ emission into the atmosphere may be significantly higher compared to that in summer. In contrast, the winter-time period leading to full freezing of the water column is unlikely to build up a significant GHG concentration under the ice and appreciably affect the gas regime of thermokarst lakes on the annual scale.

\section{The Supplement related to this article is available online at doi:10.5194/bg-12-3009-2015-supplement.}

Author contributions. R. M. Manasypov performed sampling, analysis of major cations and trace elements, interpretation and statistical treatment; V. P. Shevchenko and S. Kirpotin were responsible for the choice of sampling objects and logistics and statistical treatment; I. V. Kritzkov was the leader of the winter sampling campaign and interpretation of lake freezing results; S. V. Loiko 
and S. P. Kulizhsky provided the background information on soil and peat, and contributed to the design and interpretation of the summer, autumn and winter sampling campaigns; L. S. Shirokova was in charge of DOC, DIC and anion measurements and their interpretation; V. P. Shevchenko provided the expertise and practical performance of ice core sampling, handling and analyses; L. G. Kolesnichenko provided GIS-based interpretation, mapping and identification of sampled water bodies; V. A. Zemtzov and V. V. Sinkinov performed all primary hydrological data collection, their analysis and interpretation; and O. S. Pokrovsky and S. N. Kirpotin provided supervision and placed this work in the context of current knowledge of western Siberia thermokarst lakes. All 12 authors spent a significant amount of time in the field at the Khanymey and Nojabrsk test sites. Each co-author has seen and approved the final paper and contributed to writing the manuscript.

Acknowledgements. This work was supported by BIO-GEO-CLIM grant no. 14.B25.31.0001 of the Russian Ministry of Science and Education and Tomsk State University, ANR CESA "Arctic Metals", RFBR 14-05-31457 mol_a and grant MK-3684.2015.5. We thank two anonymous reviewers for their constructive comments.

Edited by: V. Brovkin

\section{References}

Audry, S., Pokrovsky, O. S., Shirokova, L. S., Kirpotin, S. N., and Dupré, B.: Organic matter mineralization and trace element post-depositional redistribution in Western Siberia thermokarst lake sediments, Biogeosciences, 8, 3341-3358, doi:10.5194/bg8-3341-2011, 2011.

Avagyan, A., Runkle, B. R. K., and Kutzbach, L.: Application of high-resolution spectral absorbance measurements to determine dissolved organic carbon concentration in remote areas, J. Hydrol., 517, 435-446, 2014.

Benedetti, M. F., Milne, C., Kinniburgh, D., van Riemsdijk, W., and Koopal, L.: Metal ion binding to humic substances: Application of the non ideal competitive adsorption model, Environ. Sci. Technol., 29, 446-457, 1995.

Berg, B.: Litter decomposition and organic matter turnover in northern forest soils, Forest Ecol. Manag., 133, 13-22, 2000.

Boike, J., Kattenstroth, B., Abramova, K., Bornemann, N., Chetverova, A., Fedorova, I., Fröb, K., Grigoriev, M., Grüber, M., Kutzbach, L., Langer, M., Minke, M., Muster, S., Piel, K., Pfeiffer, E.-M., Stoof, G., Westermann, S., Wischnewski, K., Wille, C., and Hubberten, H.-W.: Baseline characteristics of climate, permafrost and land cover from a new permafrost observatory in the Lena River Delta, Siberia (1998-2011), Biogeosciences, 10, 2105-2128, doi:10.5194/bg-10-2105-2013, 2013.

Bouchard, F., Francus, P., Pienitz, R., Laurion, I., and Feyte, S.: Subarctic thermokarst ponds: investigating recent landscape evolution and sediment dynamics in thawed permafrost of Northern Québec (Canada), Arctic, Antarctic and Alpine Res., 46, 251271, 2014

Dillon, P. J. and Molot, L. A.: Dissolved organic and inorganic carbon mass balances in central Ontario lakes, Biogeochemistry, 36, 29-42, 1997.
Fraysse, F., Pokrovsky, O. S., and Meunier, J.-D.: Experimental study of terrestrial plant litter interaction with aqueous solutions, Geochim. Cosmochim. Ac., 74, 70-84, 2010.

Frey, K. E. and Smith, L. C.: Amplified carbon release from vast West Siberian peatlands by 2100 , Geophys. Res. Lett., 32, L09401, doi:10.1029/2004GL022025, 2005.

Frey, K. E., Siegel, D. I., and Smith, L. C.: Geochemistry of west Siberian streams and their potential response to permafrost degradation, Water Resour. Res., 43, W03406, doi:10.1029/2006WR004902, 2007.

Grosse, G., Jones, B., and Arp, C.: Thermokarst lakes, drainage, and drained basins, in: Treatise on Geomorphology, edited by: Shroder, J., Giardino, R., and Harbor, J., Academic Press, San Diego, CA, vol. 8, Glac. Periglac. Geomorphol., 325-353, 2013.

Gustafsson, J.: WinHumicV for Win95/98/NT, 1999. http:// vminteq.lwr.kth.se/, a Windows version of MINTEQA2 website, Gustafsson, J.; www.lwr.kth.se/English/OurSoftware/vminteq/ index.htm (last access: 20 May 2015), 1999.

Jansson, M., Hickler, Th., Jonsson, A., and Karlsson, J.: Links between terrestrial primary production and bacterial production and respiration in lakes in a climate gradient in subarctic Sweden, Ecosystems, 11, 367-376, 2008.

Karlsson, J., Giesler, R., Persson, J., and Lundin, E.: High emission of carbon dioxide and methane during ice thaw in high latitude lakes, Geophys. Res. Lett., 40, 1123-1127, 2013.

Karlsson, J. M., Lyon, S. W., and Destouni, G.: Thermokast lake, hydrological flow and water balance indicators of permafrost change in Western Siberia, J. Hydrol., 464/465, 459-466, 2012.

Karlsson, J. M., Lyon, S. W., and Destouni, G.: Temporal behavior of lake size-distribution in a thawing permafrost landscape in Northwestern Siberia, Remote Sens., 6, 621-636, 2014.

Kim, K., Choi, W., Hoffmann, M. R., Yoon, H.-I., and Park, B.K.: Photoreductive dissolution of iron oxides trapped in ice and its environmental implications, Environ. Sci. Technol., 44, 41424148, 2010.

Kim, K., Yoon, H.-I., and Choi, W.: Enhanced dissolution of manganese oxide in ice compared to aqueous phase under illuminated and dark conditions, Environ. Sci. Technol., 46, 13160-13166, 2012.

Kirpotin, S. N., Polishchuk, Y. M., Zakharova, E., Shirokova, L., Pokrovsky, O., Kolmakova, M., and Dupré, B.: One of possible mechanisms of thermokarst lakes drainage in West-Siberian North, Int. J. Environ. Stud., 65, 631-635, 2008.

Larouche, J. R., Abbott, B. W., Bowden, W. B., and Jones, J. B.: The role of watershed characteristics, permafrost thaw, and wildfire on dissolved organic carbon biodegradability and water chemistry in Arctic headwater streams, Biogeosciences Discuss., 12, 4021-4056, doi:10.5194/bgd-12-4021-2015, 2015.

Laurion, I., Vincent, W. F., MacIntyre, S., Retamal, L., Dupont, C., Francus, P., and Pienitz, R.: Variability in greenhouse gas emissions from permafrost thaw ponds, Limnol. Oceanogr., 55, 115133, 2010.

Manasypov, R. M., Pokrovsky, O. S., Kirpotin, S. N., and Shirokova, L. S.: Thermokarst lake waters across the permafrost zones of western Siberia, The Cryosphere, 8, 1177-1193, doi:10.5194/tc-8-1177-2014, 2014.

Milne, C. J., Kinniburgh, D. G., van Riemsdijk, W. H., and Tipping, E.: Generic NICA-donnan model parameters for metal-ion bind- 
ing by humic substances, Environ. Sci. Technol., 37, 958-971, 2003.

Muller, S., Vahatalo, A. V., Stedmon, C. A., Granskog, M. A., Norman, L., Aslam, S., Underwood, G. J. C., Dieckmann, G. S., and Thomas, D. N.: Selective incorporation of dissolved organic matter (DOM) during sea ice formation, Mar. Chem., 155, 148-157, 2013.

Novikov, S. M.: Hydrology of Bog Territories of the Permafrost Zone of Western Siberia, St Petersbourg, BBM Publ. House, in Russian (ISBN 978-5-9651-0339-3), 536 pp., 2009.

Negandhi, K., Laurion, I., Whiticar, M. J., Galand, P. E., Xu, X., and Lovejoy, C.: Small thaw ponds: An accounted source of methane in the Canadian high Arctic, Plos One, 8, e78204, doi:10.1371/journal.pone.0078204, 2013.

Pokrovsky, O. S., Shirokova, L. S., Kirpotin, S. N., Audry, S., Viers, J., and Dupré, B.: Effect of permafrost thawing on organic carbon and trace element colloidal speciation in the thermokarst lakes of western Siberia, Biogeosciences, 8, 565-583, doi:10.5194/bg-8565-2011, 2011.

Pokrovsky, O. S., Shirokova, L. S., Zabelina, S. A., Vorobieva, T. Y, Moreva, O. Y., Klimov, S. I., Chupakov, A. V., Shorina, N. V., Kokryatskaya, N. M., Audry, S., Viers, J., Zouite, C., and Freydier, R.: Size fractionation of trace elements in a seasonally stratified boreal lake: control of organic matter and iron colloids, Aquat. Geochem., 18, 115-139, 2012.

Pokrovsky, O. S., Shirokova, L. S., Kirpotin, S. N., Kulizhsky, S. P., and Vorobiev, S. N.: Impact of western Siberia heat wave 2012 on greenhouse gases and trace metal concentration in thaw lakes of discontinuous permafrost zone, Biogeosciences, 10, 5349-5365, doi:10.5194/bg-10-5349-2013, 2013.

Pokrovsky, O. S., Shirokova, L. S., and Kirpotin, S. N.: Biogeochemistry of Thermokarst Lakes of Western Siberia, Nova Science Publ. Inc., NY, 163 pp., 2014.

Rautio, M., Dufresne, F., Laurion, I., Bonilla, S., Vincent, W. F., and Christoffersen, K.: Shallow freshwater ecosystems of the circumpolar Arctic, Ecoscience, 18, 204-222, 2011.

Shirokova, L. S., Pokrovsky, O. S., Kirpotin, S. N., and Dupré, B.: Heterotrophic bacterio-plankton in thawed lakes of the northern part of Western Siberia controls the $\mathrm{CO}_{2}$ flux to the atmosphere, Int. J. Environ. Stud., 66, 433-445, 2009.

Shirokova, L. S., Pokrovsky, O. S., Viers, J., Klimov, S. I., Moreva, O. Yu., Zabelina, S. A., Vorobieva, T. Ya., and Dupré, B.: Diurnal variations of trace metals and heterotrophic bacterioplankton concentration in a small boreal lake of the White Sea basin, Ann. Limnol.-Int. J. Lim., 46, 67-75, 2010.

Shirokova, L. S., Pokrovsky, O. S., Kirpotin, S. N., Desmukh, C., Pokrovsky, B. G., Audry, S., and Viers, J.: Biogeochemistry of organic carbon, $\mathrm{CO}_{2}, \mathrm{CH}_{4}$, and trace elements in thermokarst water bodies in discontinuous permafrost zones of Western Siberia, Biogeochemistry, 113, 573-593, 2013.

Stepanova, V. M., Pokrovsky, O. S., Viers, J., MironychevaTokareva, N. P. Kosykh, N. P., and Vishnyakova, E. K.: Major and trace elements in peat profiles in Western Siberia: impact of the landscape context, latitude and permafrost coverage, Appl. Geochem., 53, 53-70, 2015.

Tank, S. E., Esslein, R. H. H., and Esack, L. F. W. L.: Northern delta lakes as summertime $\mathrm{CO}_{2}$ absorbers within the arctic landscape, Ecosystems, 12, 144-157, 2009.
Tank, S. E., Lesack, L. F. W., Gareis, J. A. L., Osburn, C. L., and Hesslein, R. H.: Multiple tracers demonstrate distinct sources of dissolved organic matter to lakes of the Mackenzie Delta, western Canadian Arctic, Limnol. Oceanogr., 56, 1297-1309, 2011.

Unsworth, E. R., Warnken, K. W., Zhang, H., Davison, W., Black, F., Buffle, J., Cao, J., Cleven, R., Galceran, J., Gunkel, P., Kalis, E., Kistler, D., Van Leeuwen, H. P., Martin, M., Noël, S., Nur, Y., Odzak, N., Puy, J., Van Riemsdijk, W., Sigg, L., Temminghoff, E., Tercier-Waeber, M.-L., Toepperwien, S., Town, R. M., Weng, L., and Xue, H.: Model predictions of metal speciation in freshwaters compared to measurements by in situ techniques, Environ. Sci. Technol., 40, 1942-1949, 2006.

Vasyukova, E. V., Pokrovsky, O. S., Viers, J., Oliva, P., Dupré, B., Martin, F., and Candaudap, F.: Trace elements in organic- and iron-rich surficial fluids of the boreal zone: Assessing colloidal forms via dialysis and ultrafiltration, Geochim. Cosmochim. Ac., 74, 449-468, 2010.

Walter, K. M., Zimov, S. A., Chanton, J. P., Verbyla, D., and Chapin III, F. S.: Methane bubbling from Siberian thaw lakes as a positive feedback to climate warming, Nature, 443, 71-75, 2006.

Walter, K. M., Chanton, J. P., Chapin III, F. S., Schuur, E. A. G., and Zimov, S. A.: Methane production and bubble emissions from arctic lakes: Isotopic implications for source pathways and ages, J. Geophys. Res., 113, G00A08, doi:10.1029/2007JG000569, 2008.

Walter Anthony, K. M. and Anthony, P.: Constraining spatial variability of methane ebullition in thermokarst lakes using point-process models, J. Geophys. Res., 118, 1015-1034, doi:10.1002/jgrg.20087, 2013.

Walter Anthony, K. M., Anthony, P., Grosse, G., and Chanton, J.: Geologic methane seeps along boundaries of Arctic permafrost thaw and melting glaciers, Nat. Geosci., 5, 419-426, 2012.

Walter Anthony, K. M., Zimov, S. A., Grosse, G., Jones, M. C., Anthony, P. M., Chapin III, F. S., Finlay, J. C., Mack, M. C., Davydov, S., Frenzel, P., and Frolking, S.: A shift of thermokarst lakes from carbon sources to sinks during the Holocene epoch, Nature, 511, 452-456, 2014.

Weishaar, J. L., Aiken, G. R., Bergamaschi, B. A., Fram, M. S., Fujii, R., and Mopper, K.: Evaluation of specific ultraviolet absorbance as an indicator of the chemical composition and reactivity of dissolved organic carbon, Environ. Sci. Technol., 37, 47024708, 2003.

Yeghicheyan, D., Bossy, C., Bouhnik Le Coz, M., Douchet, C., Granier, G., Heimburger, A., Lacan, F., Lanzanova, A., Rousseau, T. C. C., Seidel, J.-L., Tharaud, M., Candaudap, F., Chmeleff, J., Cloquet, C., Delpoux, S., Labatut, M., Losno, R., Pradoux, C., Sivryn Y., and Sonke, J. E.: A Compilation of silicon, rare earth element and twenty-one other trace element concentrations in the natural river water reference material SLRS-5 (NRC-CNRC), Geostand. Geoanal. Res., 37, 449-467, 2014.

Zakharova, E. A., Kouraev, A. V., Kolmakova, M. V., Mognard, N. M., Zemtsov, V. A., and Kirpotin, S. N.: The modern hydrological regime of the northern part of Western Siberia from in situ and satellite observations, Int. J. Environ. Stud., 66, 447-463, 2009.

Zakharova, E. A., Kouraev, A. V., Frédérique R., Zemtsov, V. A., and Kirpotin, S. N.: Seasonal variability of the Western Siberia wetlands from satellite radar altimetry, J. Hydrol., 512, 366-378, 2014. 